\title{
Preparing Citizens for Peaceful Living: An Evaluation of Obafemi Awolowo University Curriculum for Peace Education
}

\author{
Dr Adeola Ogunrin \\ Department of Adult Education And Lifelong Learning, \\ Faculty of Education, Obafemi Awolowo University, Ile-Ife, Nigeria
}

\begin{abstract}
This article evaluated Obafemi Awolowo University's special electives and faculty general courses to determine their peace education contents and their potentials to build the capacity of undergraduates for peace living in the society. Using a peace education evaluative framework specifically designed for the study, 60 courses were evaluated for their peace contents. Results were qualitatively described in words and with the use of simple frequency tables and graphs.Findings showed that Obafemi Awolowo University offers 24 special electives consisting of 201 topics with $20.3 \%$ of peace education diet while 15 courses have peace education diet, 9 courses have none. $1.4 \%$ of the contents of the special elective curriculum reflect elements of education for peace. Human right education $1.4 \%$, Gender education $0.4 \%$, Environmental education $2.9 \%$, Futures education $7.4 \%$, Global citizenship education $0.4 \%$ and multi-cultural education $6.4 \%$. Of the general courses of the 13 faculties in the university, only 5 faculties have peace education contents. Faculty of Administration 7.1\%, Faculty of Agriculture $21.7 \%$,Faculty of Education $12.5 \%$,Faculty of Law $5 \%$, and Faculty of Social Sciences $57.1 \%$. The two most frequent peace education elements in Obafemi Awolowo University curriculum are Futures Education and Environmental Education.There are therefore convincing empirical evidence suggesting that Obafemi Awolowo University curriculum has low peace content.The term peace is frequently and liberally used in the media the public and the private sector as well as in the International arena. Peace is a key term for education because it pertains to the basic condition of human existence and societal as well as political embedding. Defining peace is a difficult task as it encompasses not only a concept but also a plethora of behaviours and conditions that could be necessary to obtain peace. The most common definition of peace states that peace is the absence of war or protracted conflict. Peace can also be seen as an attitude, behaviour, specific relation among people or quality of relations (Waterkamp 2006). The concept of peace has evolved throughout history as a result of changes in the world order and modifications in a state of existence. Moreover, in the modern world, understanding of peace varies significantly within cultural and geographical contexts. Galtung (1969), one of the best known theorists of modern peace research, defines peace through social goals as a major part of a scientific strategy. The terms peace and violence are closely linked to each other. Harris and Morrison (2003) elaborate that peace is concerned with different forms of violence and it functions at multiple levels of human existence. Traditionally, peace is associated to nations and their ability to settle disagreements. Peace is a concept that motivates and inspires imagination indicating more than the absence of violence. It implies co-operation, respect for life and human rights and the dignity of each human being without discrimination or prejudice (Burns and Aspeslagh 1983, Bajaj 2008).Since independence, Nigeria has not escaped a season that was free of crises both at community level and within ethnic groups in the country. There were political crises as well 1.0 can count up to fifty or more religious crises from 1977 till 2000 (Alabi 2010). In spite of the conflict prone situation in Nigeria, her desire for peace is evident in her national anthem and the pledge.
\end{abstract}

DOI: $10.7176 / \mathrm{JEP} / 12-25-04$

Publication date:September $30^{\text {th }} 2021$

\subsection{STATEMENT OF THE PROBLEM}

That Nigeria is a multi-ethnic society has a lot of implications on the unity of the country. Most of the ethnic crises are caused by no factor other than tribal sentiments, greed, selfishness and chauvinism. In Nigeria, there have been cases of inter-ethnic crises. There are many cases of boundary disputes such as the one between Modakeke and Ife in Osun state, Ipoti and Iloro in Ekiti state just to mention a few. The crises between university undergraduates and the school authority are so rampant while political crises disrupt progress in all ramifications almost at all times. Consequently, these also bring disturbances to the peace of Nigerians, also the common occurrences of armed robbery, ritual killings and incessant fuel crises. Undoubtedly, there is a problem of peace issues in Nigeria. The need for solutions to the numerous problems that have been causing disturbances in Nigeria is therefore strongly needed. The author therefore assumes that if peace education could be inseminated into the university curriculum, the capacity for peace of millions of graduates produced every year could significantly increase peace capacity in Nigeria

In achieving the main purpose of this study, the following objectives have been highlighted:

- To evaluate the OAU curriculum and determine the consistence of its Special Electives with the NUC

Benchmark in its peace education contents; 
- To evaluate OAU Special Electives for elements of peace education;

- To evaluate compulsory faculty courses of each faculty and determine the peace education contents in them;

- To determine the contents of peace education for students in each faculty.

Having examined the foundational perspectives, goals, and types of Peace Education, this section presents an overview of the core concepts that have shaped the field of PE. Whether emphasizing human rights, multiculturalism, international development, environmental education or conflict resolution, PE research and practice are combined by certain concepts and principles. These concepts presented here are not the only ones that exist, nor are they fixed as scholars continue to contribute to shaping how these concepts are structured, organized and utilized (Bajaj, 2008). Below, are the selected list of certain key concepts of PE which strongly relate to the current study followed by the summary of their contents used as the instrument for analysis of the current study.

Table 1: PEACE ELEMENTS EVALUATIVE FRAMEWORK

\begin{tabular}{|c|c|c|}
\hline $\mathbf{S} / \mathbf{N}$ & Concepts in Peace Education & Contents of concepts \\
\hline 1. & Education for Peace: & $\begin{array}{l}\text { - Awareness of own needs, self-awareness; } \\
\text { - Understanding nature of conflict and peace; } \\
\text { - Ability to identify causes of conflict, and non-violent means } \\
\text { - } \text { Of resolution; Conflict analysis; Mediation process } \\
\text { - Understanding of rights and responsibilities } \\
\text { - } \quad \text { societies } \\
\text { Awareness of cultural heritage }\end{array}$ \\
\hline 2. & Critical peace education: & $\begin{array}{ll}\text { - } & \text { explicit understanding of peace education as a criticism of } \\
& \text { society } \\
\text { - } & \text { structural violence } \\
\text { - } & \text { organized peacelessness } \\
\text { - } & \text { organized peacelessness participation }\end{array}$ \\
\hline 3. & Disarmament education: & 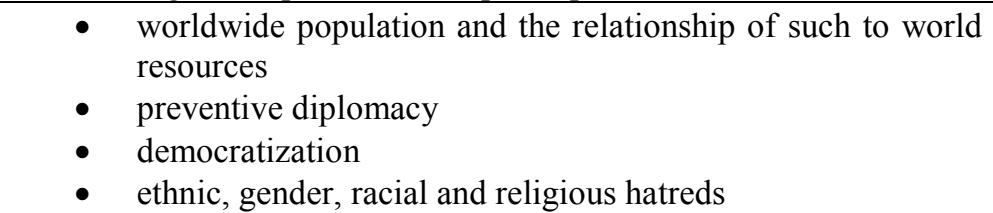 \\
\hline 4. & Human Right Education: & $\begin{array}{ll}\text { - } & \text { Right to life } \\
\text { - } & \text { Freedom from torture } \\
\text { - } & \text { Freedom from slavery } \\
\text { - } & \text { Right to a fair trial } \\
\text { - } & \text { Freedom of speech } \\
\text { - } & \text { Freedom of thought, conscience and religion } \\
\text { - } & \text { Rights to debates }\end{array}$ \\
\hline 5. & Gender Education & $\begin{array}{l}\text { Equality of women and men, girls and boys; equal education } \\
\text { for female and male } \\
\text { - } \quad \text { Self-respect, positive self-image, strong self-concept }\end{array}$ \\
\hline 6. & Environmental Education: & $\begin{array}{l}\text { - Awareness and sensitivity about the environment and } \\
\text { environmental challenges } \\
\text { - Knowledge and understanding about the environment and } \\
\text { environmental challenges } \\
\text { - Attitude concern for the environment and help to maintain } \\
\text { environmental quality } \\
\text { - Skills to mitigate the environmental problems } \\
\text { - Participation for exercising existing knowledge and } \\
\text { environmental related programs. }\end{array}$ \\
\hline 7. & $\begin{array}{l}\text { Conflict } \\
\text { education: }\end{array}$ & $\begin{array}{l}\text { - Understanding of the origins of conflict } \\
\text { - } \quad \text { an examination of why people choose particular conflict } \\
\text { prosecution (or resolution) strategies } \\
\text { - } \quad \text { investigating who escalates when and why } \\
\text { - } \quad \text { Constructive conflict resolution } \\
\text { - Mediation }\end{array}$ \\
\hline
\end{tabular}




\begin{tabular}{|c|c|c|}
\hline 8 & Futures Education & $\begin{array}{l}\text { - Content of future education include cooperation, negotiation, } \\
\text { communication, decision-making, problem-solving, coping } \\
\text { with emotions, self-awareness, empathy, critical and creative } \\
\text { thinking, dealing with peer pressure, awareness of risk, } \\
\text { assertiveness, and preparation for the world of work }\end{array}$ \\
\hline 9 & Global citizenship education & $\begin{array}{l}\text { Global citizenship allow young adults to have a critical pondering on: } \\
\text { - Citizenship } \\
\text { - Globalization } \\
\text { - Diversity } \\
\text { - Civic education } \\
\text { - Participation in society on behalf of peace }\end{array}$ \\
\hline 10 & Multi-cultural education & $\begin{array}{l}\text { - It prepares all students to work actively toward structural } \\
\text { equality in organizations and institutions. } \\
\text { - Understanding skills for the redistribution of power and } \\
\text { income among diverse groups. } \\
\text { - Issues of racism, sexism, classism, linguicism, ableism, } \\
\text { ageism, heterosexism, religious intolerance, and xenophobia. }\end{array}$ \\
\hline
\end{tabular}

\subsection{THEORETICAL FRAMEWORK}

Based on the insights emerging from peace education research and lessons learned from five years of implementation of the Education for Peace (EFP) programme, four prerequisite conditions for effective peace education are identified. These prerequisites also constitute the main components of peace education. In other words, the requirements and components of effective peace education are identical and give peace education a self-regenerative and organic quality. Thus, peace is a requirement for effective peace education, and peace education creates higher states of peace.

In this theory each of the four prerequisites for effective peace education are described; the main principles of the Integrative Theory of Peace (ITP) are outlined; and a brief review of the EFP programme, formulated within the framework of ITP, is provided. The main components of EFP are discussed throughout the paper.

Prerequisite I: truly effective peace education can only take place in the context of a unity-based worldview. Peace education and civilization are inseparable dimensions of human progress. Expressed differently, peace education is the only route to true civilization and true civilization is both peaceful and peace creating. However, in practice, nearly all segments of society ignore this fundamental fact and train every new generation of children [and youth in accordance with conflict-based perspectives. The reason why peace education is 'such a difficult task', Ruth Firer (2002, p. 55) observes, is 'the continuous war education that youngsters and adults have been receiving since the beginning of mankind'. Firer's observation is validated when we critically review the current underlying worldviews that shape and inform our pedagogical philosophies and practices and it becomes evident that most current approaches to education revolve around the issues of conflict, violence and war. This is equally true about education at home, in school, within the community, through the example of ethnic and national heroes and leaders and through the mass media (television, Internet and the entertainment and recreation industry).

In the context of family, not infrequently, parents find themselves facing conflicts that they are often unable to resolve effectively and positively. Many parents also - intentionally or inadvertently — provide their children with the notion that the primary purpose of life is to ensure one's own survival, security and success in a dangerous, conflicted and violent world. Many teach their children that the most primal and powerful forces operating in life are those of competition and struggle. Children receive the same message from other influential sources of education in their homes, namely television, Internet and games.

In school, children once again are introduced to these conflict-based views through the actual experience of school life - with its culture of otherness, conflict, competition, aggression, bullying and violence - and through concepts provided by teachers and textbooks that further validate these conflict-oriented ideas and experiences. History textbooks, by and large, are the accounts of rivalries, conflicts, wars, conquests and defeats, with men as the main actors on the stage of social life. Many works of literature are renditions of the same processes in dramatic, emotionally charged and highly stirring manner. In biology classes, the emphasis is on survival and struggle that is observed at all levels of life. However, issues of coexistence, interdependence and cooperation - factors that are at the core of both formation and maintenance of life - are often given less attention and credence. In social studies, children are taught the dynamics of in-group and out-group and the notions of foreignness and otherness. Political science revolves around issues of power, competition, winning and losing and economic theories promote various concepts based on the notion of the survival of the fittest. We teach our children that the world is a jungle, that life is the process of survival in this jungle and that power is the essential tool to emerge victorious in this highly conflicted and violence-prone world. It is, therefore, not surprising that every new generation matures with much 
greater familiarity, certainty and comfort with the ways of conflict, competition and violence than those of harmony, cooperation and peace.

Truly effective peace education can only take place when the conflict-based worldviews which inform most of our educational endeavours are replaced with peace based worldviews. Duffy (2000, p. 26), in a detailed review of peace education efforts aimed at creating a culture of peace in Northern Ireland, concludes that it is difficult to be optimistic about the long-term possibilities of promoting change' in conditions of conflict in Northern Ireland unless a 'dynamic model of education' is introduced that 'will encourage young people in Northern Ireland to question the traditional sectarian values of their homes'. In his review of various approaches to peace education in Northern Ireland, Duffy observes that no satisfactory approach has been found, despite considerable effort and expenditure of human and financial resources.

This theory maintains that nothing short of a comprehensive, all-inclusive and sustained curriculum of education for peace could possibly alter the current attitudes and worldviews that contribute so greatly to conflict, violence and war afflicting human societies worldwide. In fact, it is my assertion that a comprehensive programme of peace education should constitute the foundation and provide the framework for all curricula in schools everywhere. The long, disturbing history of human conflict and education's role in promoting conflict-based worldviews demand a new approach to education delivered within the framework of peace principles.

In fact there are some positive and hopeful signs that a new consciousness regarding the need for a change in our approach to education is emerging. An example is the work of the United Nations Education, Scientific and Cultural Organization (UNESCO, 1998) that sees 'education as the key means to spearhead the movement towards a culture of peace'. Another example of this awareness is reflected in the inclusion of the issue of education in various attempts at peace between Israeli and Palestinian negotiators, who during their Oslo I, Oslo II, and Wye Plantation Agreements agreed to remove all hostile, inaccurate, untrue and misleading propaganda from their respective communities, including school curricula. In particular, the Palestinian Authority agreed to remove from its textbooks all prejudicial references against Israel. However, as Israeli (1999) has observed, the Palestinian Authority has not fulfilled this commitment, a fact that has contributed negatively to the Israeli-Palestinian relationships.

Currently, concerted efforts are under way by the authorities of the Government of Bosnia and Herzegovina and the international community in that country to create a school curriculum that will educate students in the principles of interethnic harmony, collaboration and peace, rather than the opposite, as has been the case (Spaulding, 1998; Hays, 2002; OSCE, 2005a). This attention to issues of education and peace is not surprising, because it is through education that our worldviews are profoundly influenced and shaped, and it is through the framework of our worldviews that we become suspicious or trusting, conflicted or united, peaceful or violent.

\section{Prerequisite II: peace education can best take place in the context of a culture of peace}

In a review of 50 years of research on peace education, Vriens (1999, pp. 48-49) finds that peace education is a difficult task even in relatively more peaceful communities and concludes that although 'studies of children's conceptions of war and peace are very important for the realisation of a balanced peace education strategy', nevertheless, 'research cannot tell us what peace education should be'. Peace research has a better potential to tell us what should not be done, rather than what we need to do to create peace. However, common sense dictates that we cannot educate our children and youth about peace in an environment of conflict and violence. Therefore, in May 2000, when the implementation of the EFP programme in six primary and secondary schools in BiH started, their primary objective was to attempt to create a culture of peace in and between these schools along the parameters outlined by the United Nations (1998):

The culture of peace is based on the principles established in the Charter of the United Nations and on respect for human rights, democracy and tolerance, the promotion of development, education for peace, the free flow of information and the wider participation of women as an integral approach to preventing violence and conflicts, and efforts aimed at the creation of conditions for peace and its consolidation (A/Res/52/13, 15 January 1998, para. 2).

The discrepancy between theory and practice always has a detrimental impact on students' learning processes as it places them in a state of conflict between what is said and what is done. It is for this reason that peace education needs to help the students to develop a worldview based on peace principles within a peace-based environment. As UNESCO states, 'first and foremost, a culture of peace implies a global effort to change how people think and act in order to promote peace' (UNESCO, 1998, p. 1).

The issue of the necessity of change of mind-set and the behaviour emanating from it is not only a social and political necessity, but is also strongly needed in the religious thinking of people and their leaders. It is a fact that religions have always played, and continue to play, a cardinal role in the worldview and behaviour of their followers and not infrequently have been, and continue to be, the cause of conflict and war in human history. The following statement is of a particular importance with regards to the role of religion in development of peace:

Religion should unite all hearts and cause wars and disputes to vanish from the face of the earth; it should give birth to spirituality, and bring light and life to every soul. If religion becomes a cause of dislike, hatred and 
division it would be better to be without it, and to withdraw from such a religion would be a truly religious act ... Any religion which is not a cause of love and unity is no religion ('Abdu'l-Bahá, 1961, p. 130).

However, the task of worldview transformation is very difficult, even under normal conditions. But, under conditions of conflict, violence and war a new and more fundamental challenge to the goal of changing 'how people think' is encountered. Conflict and violence afflict and damage all aspect of human life. They destroy the physical habitat of people. They inflict physical and psychological injuries on people. They cause social dislocation, poverty and disease and weaken the moral and spiritual fabric of individual and community life. Conflict, violence and war negatively impact every aspect of life: environmental, medical, psychological, economic, social, moral and spiritual. These injuries make the task of creation of a culture of peace very difficult and point to yet another prerequisite condition for effective peace education - a culture of healing. Successful peace education can only take place in a peace-oriented milieu - a culture of peace-which in turn requires the opportunity for the participants to heal their conflict-inflicted injuries in the context of a healing environment.

\section{Prerequisite III: peace education best takes place within the context of a culture of healing}

One wide-ranging review of peace education activities and research concludes that 'peace education is an extremely difficult task in war and post-war situations primarily because of the tremendous need for children to overcome the catastrophic impact of war on all aspects of their lives and grieve their monumental losses' (Vriens 1999, p. 46). Ervin Staub (2002), reporting on his work in Rwanda, points to the importance of healing from trauma and states that 'without such healing, feeling vulnerable and seeing the world as dangerous, survivors of violence may feel that they need to defend themselves from threat and danger. As they engage in what they see as selfdefence, they can become perpetrators' (p. 83). Here, Staub is describing the relationship between culture of healing and culture of peace.

\section{Prerequisite IV: peace education is most effective when it constitutes the framework for all educational activities}

The first three prerequisite conditions for peace education - the need for a unity based worldview, a culture of peace and a culture of healing - together point to the need for a peace-based curriculum. The notion of peacebased curriculum demands a total reorientation and transformation of our approach to education with the ultimate aim of creating a civilization of peace, which is at once a political, social, ethical and spiritual state. Political and social dimensions of peace have historically received considerable attention, and in recent decades, moral and ethical aspects of peace have also been incorporated in humanity's agenda, through national and international declarations of human rights and focus on the issue of nonviolence.

However, the spiritual aspect of peace has received considerably less attention, which is especially significant in the light of current political and social dialogue about the place of religion and spirituality in the individual and collective life of humanity. This is so because, as is evident in our world today and as the history so graphically demonstrates, the political, social, legal and ethical efforts of leaders and peoples combined cannot yield their ultimate desired result - peace. Peace in its essence is a spiritual state with political, social and ethical expressions. The human spirit must be civilized before we can create a progressive material, social and political civilization. Peace must first take place in human consciousness - in our thoughts, sentiments and objectives — which are all shaped by the nature and focus of our education. To meet these requirements, the peace education curriculum needs to integrate and pay equal attention to all aspects of peace: its psychological roots; social, economic and political causes; moral and ethical dimensions; and transcendent spiritual foundations. Without any of these factors, achievement of peace remains an aspiration rather than an established reality.

Such a comprehensive, sustainable, restorative, transformative, inclusive and integrative programme of peace education requires a multifaceted and multi-level approach. This curriculum needs to be formulated within the framework of a peace-based worldview. It needs to take into consideration the developmental processes of human understanding and consciousness that shape the nature and quality of our responses to the challenges of life both at individual and collective levels. A comprehensive peace education must address the all-important issue of human relationships. At home, in school and within the community, children and youth are constantly learning about relationships, if not in a measured, thoughtful, systematic manner, then in a haphazard, careless and injurious manner. This curriculum must teach the children and youth not only the causes of conflict, violence and war and the ways of preventing and resolving them, but also the dynamics of love, unity and peace at individual, interpersonal, intergroup and universal levels. In the words of Pierre Teilhard de Chardin (1961): 'Love alone is capable of uniting living beings in such a way as to complete and fulfil them, for it alone takes them and joins them by what is deepest in themselves' (pp. 291-292).

\section{The Integrative Theory of Peace}

The Integrative Theory of Peace (ITP) is based on the concept that peace is, at once, a psychological, social, political, ethical and spiritual state with expressions at intrapersonal, interpersonal, intergroup and international areas of human life. The theory holds that all human states of being, including peace, are the outcome of the main human cognitive (knowing), emotive (loving) and conative (choosing) capacities (Danesh, 1997; Huitt, 1999a, b) which, together, determine the nature of our worldview. Within the framework of a peace-based worldview, the 
fundamental elements of a culture of peace, such as respect for human rights and freedom, assume a unique character. ITP draws from the existing body of research on issues of psychosocial development and peace education, as well as a developmental approach to conflict

Figure 1. Prerequisites and components of an effective program of Peace Education resolution (Danesh \& Danesh, 2002 a, b) and the lessons learned and observations made during five years of implementation of the Education for Peace programme in 112 schools in Bosnia and Herzegovina.

The integrative theory of peace consists of four sub theories:

- Sub theory 1: Peace is a psychosocial and political as well as a moral and spiritual condition.

- Sub theory 2: Peace is the main expression of a unity-based worldview.

- Sub theory 3: The unity-based worldview is the prerequisite for creating both a culture of peace and a culture of healing.

- Sub theory 4: A comprehensive, integrated and lifelong education within the framework of peace is the most effective approach for a transformation from the conflict-based metacategories of survival-based and identity-based worldviews to the metacategory of unity-based worldview.

ITP posits that peace has its roots at once in the satisfaction of human need for survival, safety and security; in the human quest for freedom, justice and interconnectedness; and in the human search for meaning, purpose and righteousness. Thus, peace is the ultimate outcome of our transition from self-centred and anxiety-ridden insecurities of survival instincts and the quarrelsome, dichotomous tensions of the identity-formation processes to a universal and all-inclusive state of awareness of our fundamental oneness and connectedness with all humanity and, in fact, with all life.

\section{CHAPTER THREE}

\subsection{RESEARCH METHOD}

\subsection{INTRODUCTION}

This chapter explains in detail the procedures and strategies that were employed in carrying out this study. It describes the construction, description and administration of the research, the study population and evaluation of data.

\subsection{RESEARCH DESIGN}

The urge to wipe out culture of war and violence in our societies today is enormous; hence, the researcher has set out to find out the extent to which university education orientates university graduates towards peace. In view of the nature of the study, being a documentary research, the researcher relied on secondary data on public documentary sources - Nigeria University Curriculum (NUC Benchmark); Obafemi Awolowo University Curriculum; and books on peace education.

\subsection{PROCEDURE FOR DATA COLLECTION}

In reviewing the peace contents of Obafemi Awolowo University Curriculum, the researcher developed evaluative templates which are elements of peace education and NUC Benchmark: it is with these two lenses that the researcher filters out peace contents in Obafemi Awolowo University.

Obafemi Awolowo University has 13 faculties and these faculties have some certain number of general courses which students from such faculty must partake before graduation. The course contents of these general courses were the subject of evaluation in order to determine their peace contents.

In the same vein, Obafemi Awolowo University offers a number of General courses (GNS) called Special Electives and these special elective courses are dispensed from each faculty in the university. Students are to register at least for six out of twenty four of these special elective courses before they graduate. The course contents of these special elective courses will also be the subject of evaluation to determine their peace contents.

The data for this study were collected from various sources. The researcher consulted the University calendar where he was able to get the course title and course contents of some general courses of each faculty. Those data that were not gotten through this source were gotten from course coordinators and some also from students.

The course title and contents for special electives were gotten from course coordinators and those that were not gotten from the course coordinators were gotten from students. 
Table 3.1: Faculties and the number of their combined/compulsory courses

\begin{tabular}{|l|l|l|}
\hline SN & FACULTY & NUMBER OF GENERAL COURSES \\
\hline 1 & ADMINISTRATION & 2 \\
\hline 2 & AGRICULTURE & 3 \\
\hline 3 & ART & 4 \\
\hline 4 & EDUCATION & 10 \\
\hline 5 & E.D.M & 1 \\
\hline 6 & COLLEGE of HEALTH SCIENCES ( 3 faculties) & - \\
\hline 7 & LAW & 4 \\
\hline 8 & PHARMACY & 3 \\
\hline 9 & SOCIAL SCIENCES & 2 \\
\hline 10 & SCIENCE & 6 \\
\hline 11 & TECHNOLOGY & 3 \\
\hline & & $\mathbf{3 8}$ \\
\hline
\end{tabular}

Table 3.2: Faculties and their Special Elective courses

\begin{tabular}{|c|c|c|}
\hline $\mathbf{S N}$ & FACULTY & 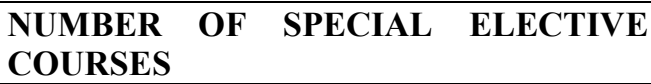 \\
\hline 1 & ADMINISRATION & 2 \\
\hline 2 & AGRICULTURE & 2 \\
\hline 3 & ART & 2 \\
\hline 4 & EDUCATION & 2 \\
\hline 5 & E.D.M & 2 \\
\hline 6 & CLINICAL SCIENCE & 1 \\
\hline 7 & PHARMACY & 2 \\
\hline 8 & LAW & 2 \\
\hline 9 & SCIENCE & 2 \\
\hline 10 & TECHNOLOGY & 1 \\
\hline \multirow[t]{2}{*}{11} & SOCIAL SCIENCES & 4 \\
\hline & TOTAL & 24 \\
\hline Numb & $\begin{array}{ll}\text { General courses } & =36 \\
\text { special elective courses }=24\end{array}$ & \\
\hline
\end{tabular}

Therefore 60 courses out of Obafemi Awolowo University curriculum were evaluated to check for their peace education contents and also to compare them with the NUC Benchmark.

\subsection{METHOD OF DATA ANALYSIS}

Having used the method of data collection explained above: the data collected were analysed using elements of peace education, coupled with Integrative Theory of Peace Education (ITP), and other appropriate qualitative data analysis method.

\section{CHAPTER FOUR}

\section{DATA ANALYSIS, INTERPRETATION AND DISCUSSION}

\subsection{INTRODUCTION}

Base on the nature of the study (an evaluation of University curriculum), we shall employ a descriptive method of data analysis. The data collected will be analyzed qualitatively using Integrative Theory of Peace Education.

\subsection{THE LEVEL OF CONSISTENCY OF OAU SPECIAL ELECTIVES CURRICULUM WITH THE} NUC BENCHMARK IN TERMS OF PEACE EDUCATION CONTENTS

In order to have a smooth analysis, it is expedient that we start by itemizing and describing the general courses recommended in the NUC Benchmark for all universities nationwide so as to filter out their peace contents. 
Table 4.1 Compulsory General Courses recommended in the NUC Benchmark and their Course Descriptions.

\begin{tabular}{|c|c|c|}
\hline $\mathbf{S N}$ & $\begin{array}{l}\text { COURSE } \\
\text { TITLE }\end{array}$ & COURSE DESCRIPTION \\
\hline 1. & $\begin{array}{l}\text { Communication } \\
\text { in English }\end{array}$ & $\begin{array}{l}\text { Effective communication and writing in English, Language skills, writing of essay } \\
\text { answers, Comprehension, Sentence construction, Outlines and paragraph, } \\
\text { Collection and organization of materials and logical presentation, Punctuation. }\end{array}$ \\
\hline 2. & $\begin{array}{l}\text { Logic philosophy } \\
\text { and human } \\
\text { existence }\end{array}$ & $\begin{array}{l}\text { A brief survey of the main branches of Philosophy Symbolic Logic Special symbols } \\
\text { in symbolic Logic-conjunction, negation, affirmation, disjunction, equivalent and } \\
\text { conditional statements law of tort. The method of deduction using rules of inference } \\
\text { and bi-conditionals qualification theory. Types of discourse, Nature or arguments, } \\
\text { Validity and soundness; Techniques for evaluating arguments; Distinction between } \\
\text { inductive and deductive inferences; etc. (Illustrations will be taken from familiar } \\
\text { texts, Including literature materials, Novels, Law reports and newspaper } \\
\text { publications). }\end{array}$ \\
\hline 3. & $\begin{array}{l}\text { Nigerian Peoples } \\
\text { and Culture }\end{array}$ & $\begin{array}{l}\text { Study of Nigerian history, culture and arts in pre-colonial times, Nigerian's } \\
\text { perception of his world, Culture areas of Nigeria and their characteristics, Evolution } \\
\text { of Nigeria as a political unit, Indigene/settler phenomenon, Concepts of trade, } \\
\text { Economic self-reliance, Social justice, Individual and national development, Norms } \\
\text { and values, Negative attitudes and conducts (cultism and related vices), Re- } \\
\text { orientation of moral Environmental problems. }\end{array}$ \\
\hline 4. & $\begin{array}{l}\text { Use of Library, } \\
\text { Study Skills and } \\
\text { Information } \\
\text { Communication } \\
\text { Technology } \\
\text { (ICT) }\end{array}$ & $\begin{array}{l}\text { Brief history of libraries, Library and education, University libraries and other types } \\
\text { of libraries, Study skills (reference services). Types of library materials, using library } \\
\text { resources including e-learning, e-materials; etc., Understanding library catalogues } \\
\text { (card, OPAC, etc.) and classification, Copyright and its implications, Database } \\
\text { resources, Bibliographic citations and referencing. Development of modern ICT, } \\
\text { Hardware technology Software technology, Input devices, Storage devices, Output } \\
\text { devices, Communication and internet services, Word processing skills (typing, etc.). }\end{array}$ \\
\hline 5. & $\begin{array}{l}\text { Communication } \\
\text { in English II }\end{array}$ & $\begin{array}{l}\text { Logical presentation of papers, Phonetics, Instruction on lexis, Art of public speaking } \\
\text { and oral communication, Figures of speech, Précis, Report writing. }\end{array}$ \\
\hline 6. & $\begin{array}{l}\text { Communication } \\
\text { in French }\end{array}$ & $\begin{array}{l}\text { Introduction to French, Alphabets and numeric for effective communication (written } \\
\text { and oral), Conjugation and simple sentence construction based on communication } \\
\text { approach, Sentence construction, Comprehension and reading of simple texts. }\end{array}$ \\
\hline 7. & $\begin{array}{l}\text { Communication } \\
\text { in Arabic }\end{array}$ & $\begin{array}{l}\text { Introduction to Arabic alphabets and writing systems, Elementary conversational } \\
\text { drills, Basic reading skills, } \\
\text { Sentence construction in Arabic. }\end{array}$ \\
\hline 8. & $\begin{array}{l}\text { History and } \\
\text { Philosophy of } \\
\text { Science }\end{array}$ & $\begin{array}{l}\text { Man - his origin and nature, Man and his cosmic environment, Scientific } \\
\text { methodology, Science and technology in the society and service of man, Renewable } \\
\text { and non-renewable resources - man and his energy resources, Environmental effects } \\
\text { of chemical plastics, Textiles, Wastes and other material, Chemical and } \\
\text { radiochemical hazards. Introduction to the various areas of science and technology. } \\
\text { Elements of environmental studies. }\end{array}$ \\
\hline 9. & $\begin{array}{l}\text { Peace Studies and } \\
\text { Conflict } \\
\text { Resolution }\end{array}$ & $\begin{array}{l}\text { Basic Concepts in peace studies and conflict resolution, Peace as vehicle of unity and } \\
\text { development, Conflict issues, Types of conflict, e. g. } \\
\text { Ethnic/religious/political/economic conflicts, Root causes of conflicts and violence } \\
\text { in Africa, Indigene/settler phenomenon, Peace- building, Management of conflict } \\
\text { and security. Elements of peace studies and conflict resolution, Developing a culture } \\
\text { of peace, Peace mediation and peace-keeping, Alternative Dispute Resolution } \\
\text { (ADR). } \\
\text { Dialogue/arbitration in conflict resolution, Role of international organizations in } \\
\text { conflict resolution, e.g. ECOWAS, African Union, United Nations, etc. }\end{array}$ \\
\hline 10. & $\begin{array}{l}\text { Introduction to } \\
\text { Entrepreneurial } \\
\text { Skills }\end{array}$ & $\begin{array}{l}\text { Introduction to entrepreneurship and new venture creation; Entrepreneurship in } \\
\text { theory and practice; The opportunity, Forms of business, Staffing, Marketing and } \\
\text { the new venture; Determining capital requirements, Raising capital; Financial } \\
\text { planning and management; Starting a new business, Feasibility studies; Innovation; } \\
\text { Legal Issues; Insurance and environmental considerations. Possible business } \\
\text { opportunities in Nigeria. }\end{array}$ \\
\hline
\end{tabular}


Table 4.2 Obafemi Awolowo University Special Electives and their Course Descriptions.

\begin{tabular}{|c|c|c|}
\hline SN & COURSE TITLE & COURSE DESCROPTION \\
\hline 1. & $\begin{array}{l}\text { SEO } \\
\text { Fundamentals } \\
\text { Human Behaviour }\end{array}$ & $\begin{array}{l}\text { The basics of human perception, memory capacity and organization, the } \\
\text { development of skill and expertise, and the characteristics of everyday reasoning } \\
\text { and decision making. For example, a central problem in information science is } \\
\text { how to label information stored for later recall. By examining how human } \\
\text { memory operates, we can gain some insight into possible schemes that may be } \\
\text { compatible with human users. This survey of what we know about the human } \\
\text { mind offers ideas about how to exploit mental capacities in the design and use } \\
\text { of information systems. }\end{array}$ \\
\hline 2. & $\begin{array}{l}\text { SEO 002: Man and } \\
\text { His Environment }\end{array}$ & $\begin{array}{l}\text { In this course students are made to undergo a field trip in which students are } \\
\text { taken to a natural environment, and there, Students are made to know } \\
\text { Government's failure to take care of such natural environment. }\end{array}$ \\
\hline 3. & $\begin{array}{l}\text { SEO 003: Principles } \\
\text { and Practices of } \\
\text { Entrepreneurship and } \\
\text { Self Employment }\end{array}$ & $\begin{array}{l}\text { In this course students are to understand what Business opportunity is; } \\
\text { Characteristics of business opportunity; Distinctions between ideas and business } \\
\text { opportunity; the process of generating screening and selection of venture ideas; } \\
\text { the entrepreneurial decision; Key success factors in setting up a small business. }\end{array}$ \\
\hline 4. & $\begin{array}{l}\text { SEO 004: Business } \\
\text { Environment and } \\
\text { Approach to Business } \\
\text { Start Up }\end{array}$ & $\begin{array}{l}\text { Students are taught how to write a business plan, when to write a business plan, } \\
\text { types of business plan, what a business plan looks like, how to organize a } \\
\text { business plan, the standard business plan format. }\end{array}$ \\
\hline 5. & $\begin{array}{l}\text { SER 001: The Use of } \\
\text { English }\end{array}$ & $\begin{array}{l}\text { Students are exposed to the four language skills i.e. writing, reading, listening } \\
\text { and speaking. }\end{array}$ \\
\hline 6. & $\begin{array}{l}\text { SER 002: } \begin{array}{r}\text { Humanity } \\
\text { and } \\
\text { Experience }\end{array} \\
\end{array}$ & $\begin{array}{l}\text { This course studies the history of African, its culture and its art; Post-colonial } \\
\text { Africa's political and economic development; The colonial experience and form } \\
\text { of literature in contemporary Africa and The features of African music and } \\
\text { theatre. }\end{array}$ \\
\hline 7. & $\begin{array}{l}\text { SEP 001: Drug and } \\
\text { Society I }\end{array}$ & $\begin{array}{l}\text { In this course, students are exposed to appropriate and bad use of drug in the } \\
\text { society, patient education, and some interventions of both private and public } \\
\text { organizations to promote rational use of drug. }\end{array}$ \\
\hline 8 . & $\begin{array}{l}\text { SEP 002: Drug and } \\
\text { Society II }\end{array}$ & $\begin{array}{l}\text { An overview of drug abuse, misuse and disuse; Conditions that predisposes } \\
\text { people to drug abuse; Common symptoms of drug abuse; Problems with drug } \\
\text { abuse; Drugs misuse; Some examples of common drug misuse; Effects of drug } \\
\text { misuse; The human environment and toxic chemicals; Emergency management } \\
\text { of poisoning. }\end{array}$ \\
\hline 9. & $\begin{array}{l}\text { SED 001: Poverty and } \\
\text { Health }\end{array}$ & $\begin{array}{l}\text { Definition of poverty and its measurement; Eradication of poverty; Achieving } \\
\text { universal pre-education ; Reducing child mortality; Improving material health; } \\
\text { Eradication of disease especially on materials; Achieving environmental } \\
\text { sustainability; Global partnership; Poverty analysis. }\end{array}$ \\
\hline 10. & $\begin{array}{l}\text { SEH 001: Man and } \\
\text { His Health }\end{array}$ & $\begin{array}{l}\text { Basic concepts of health; Courses and preventions of road accident; Medical } \\
\text { emergencies and first aid; Common medical emergencies in Nigeria; and Basic } \\
\text { life support. }\end{array}$ \\
\hline 11. & $\begin{array}{l}\text { SEH 002: Community } \\
\text { Health and Man's } \\
\text { Behaviour }\end{array}$ & $\begin{array}{l}\text { Impacts of human activities on the environment; Industrial development } \\
\text { Pollution defined; Sustainable development; Immunization and immunity; } \\
\text { Contraindication to vaccination The burden of oral diseases. }\end{array}$ \\
\hline 12. & $\begin{array}{l}\text { SES002: Man and His } \\
\text { Biological World }\end{array}$ & A brief history of biochemistry, Microbiology, and Botany \\
\hline
\end{tabular}




\begin{tabular}{|c|c|c|}
\hline $\mathrm{SN}$ & COURSE TITLE & COURSE DESCROPTION \\
\hline 13. & $\begin{array}{l}\text { SEL 001: Introduction } \\
\text { to Law }\end{array}$ & $\begin{array}{l}\text { Meaning and scope of law; A brief constitutional history of Nigeria; Definition } \\
\text { of democracy Features of democracy; Challenges of Nigerian democracy; } \\
\text { Strategies for the challenges of democracies; Nigerian security problem and } \\
\text { probable solutions; Concept of human right Relevant provisions of the } 1999 \\
\text { constitution for their protection; Definition of scope of contract; Definition of } \\
\text { criminal law; Elements of an office; Aim of criminal punishment Is death penalty } \\
\text { justified?; Concept of eutenacia; Meaning and scope of international law } \\
\text { Importance and relevance of international law; Objectives of UNO, ICC, African } \\
\text { chapter on human and people's right; What are human's right?; Effects of female } \\
\text { genital mutilation. }\end{array}$ \\
\hline 14. & $\begin{array}{l}\text { SEL 002: Introduction } \\
\text { to Legal Constitution } \\
\text { And Processes }\end{array}$ & $\begin{array}{l}\text { What is election?; Functions of election in a democratic society; Types of } \\
\text { election in democratic society; Problems of election in democratic society; } \\
\text { Meaning and features of electoral act } 2006 \text { as amended; Solutions to electoral } \\
\text { problems in Nigeria; Judicial proceeding in the Nigeria electoral society; } \\
\text { Adjudicatory systems in Nigeria before 1954, between } 1954 \text { and 1963, between } \\
\text { and } 2007 \text {. }\end{array}$ \\
\hline 15. & $\begin{array}{l}\text { SEE 001: Indigenous } \\
\text { Education }\end{array}$ & $\begin{array}{l}\text { Indigenous vs. western education; Indigenous knowledge and education; } \\
\text { Models of Indigenous Education; Methods of Indigenous education; Roles of } \\
\text { indigenous education in individual transformation; Importance of indigenous } \\
\text { education; attitudes, norms, and values of indigenous people. }\end{array}$ \\
\hline 16. & $\begin{array}{l}\text { SEE 002: Introduction } \\
\text { to Nigerian Education }\end{array}$ & $\begin{array}{l}\text { The historical development of western education in Nigeria; Indigenous moral } \\
\text { education in Nigeria; Indigenous civil administration; Nigeria indigenous and } \\
\text { economic system The meaning and purpose of traditional education in Nigeria; } \\
\text { Oral transmission of knowledge in Nigerian folklore, ethics and idioms; Political } \\
\text { system in traditional societies Language diversification in Nigeria; Overview of } \\
\text { Nigerian educational policy. }\end{array}$ \\
\hline 17. & $\begin{array}{l}\text { SEM } 001: \\
\text { Fundamentals in } \\
\text { Building and Design } \\
\text { for Human Habitation }\end{array}$ & $\begin{array}{l}\text { This course takes the students through the importance of building; types of } \\
\text { building; Functions of building in an environment; Common sanitary appliances } \\
\text { in the building; And major building industries in Nigeria. }\end{array}$ \\
\hline 18. & $\begin{array}{l}\text { SEM 002: Issues in } \\
\text { Land Management }\end{array}$ & $\begin{array}{l}\text { Estate management as an academic discipline; The concept of land; } \\
\text { Distinguishing characteristics of land; Astarte attributes of land; Economic } \\
\text { significance of land } \\
\text { Land as an exhaustible and inexhaustible resource; Permanence and safety; } \\
\text { Supply and demand for land; Factors influencing the use of land resources; The } \\
\text { land tenure system in Nigeria; Property development; Objectives of } \\
\text { development; Sale and lease back. }\end{array}$ \\
\hline 19. & $\begin{array}{lr}\text { SEA } & 001: \\
\text { Government } & \text { and } \\
\text { Administration } & \text { of } \\
\text { Public Sector } & \end{array}$ & $\begin{array}{l}\text { Public administration as an organization of government policies; Public } \\
\text { administration as an academic discipline; Public administration prepares civil } \\
\text { servants for work; Public administration advances management and policies so } \\
\text { that government can function; Public administration translates politics into the } \\
\text { reality. }\end{array}$ \\
\hline 20. & $\begin{array}{l}\text { SEA 002: Elements of } \\
\text { Business } \\
\text { Administration }\end{array}$ & $\begin{array}{l}\text { The nature and scope of accounting; The functions of accounting; Accounting } \\
\text { and its relationship with information system of organization; Accounting } \\
\text { procedures and system Double entry book-keeping systems; Profit and loss } \\
\text { accounting and balance sheet of a sale trader; Accounting treatment of control } \\
\text { accounts and bank reconciliation; The account of non-profit oriented } \\
\text { organizations; Receipt and payment versus income and expenditure accounts; } \\
\text { Incomplete records; Specialized transactions. }\end{array}$ \\
\hline 21. & $\begin{array}{l}\text { SEG 001: Food } \\
\text { Production and the } \\
\text { Nation }\end{array}$ & $\begin{array}{l}\text { The need for progress in agriculture; The roles of agriculture; Managing the } \\
\text { ecosystem Agriculture as a form of energy; Animal protein versus plant protein }\end{array}$ \\
\hline
\end{tabular}




\begin{tabular}{|l|l|l|}
\hline SN & COURSE TITLE & COURSE DESCROPTION \\
\hline 22. & $\begin{array}{l}\text { SEG 002: Agriculture } \\
\text { and Human Survival }\end{array}$ & $\begin{array}{l}\text { In this course, students are taken on a field trip to the school farm where which } \\
\text { they are shown Agro Products' as embracing a broad and all-inclusive category } \\
\text { of products related to AGRICULTURE: Agro products are seen as the life force, } \\
\text { the very source of survival for the human kind. It is not only that man breathes } \\
\text { with the support of food but a major chunk of the world population is also } \\
\text { dependent on agriculture as their source of survival; categories of agro products: } \\
\text { Cereals and Pulses, Seeds, Spices, Fruits, Vegetables, Dry Fruits \& Nuts, } \\
\text { Flowers, Fertilizers, Beverages \& Juices, Fodder, Dairy Products, Aromatic } \\
\text { Plants, Herbal Products, Agricultural Machinery and Equipment, Meat \& } \\
\text { Poultry Food, Marine Food Supplies. }\end{array}$ \\
\hline 23. & $\begin{array}{l}\text { SET 002: Technology } \\
\text { and Society }\end{array}$ & $\begin{array}{l}\text { Economics and technological development; Government funding for new } \\
\text { technology; Technology and Economics in the Future; Techno capitalism; } \\
\text { Sociological factors and effects; Values, Institutions and groups, International, } \\
\text { Environment }\end{array}$ \\
\hline 24. & $\begin{array}{l}\text { LIB 001: The Use of } \\
\text { Library }\end{array}$ & $\begin{array}{l}\text { Library services; Types of library and their various functions; The organization } \\
\text { set up of library; Technical processing of a library materials; Cataloguing; } \\
\text { Reference tools and services; Preservation of library materials. }\end{array}$ \\
\hline
\end{tabular}

\section{COURSES RECOMMENDED IN NUC THAT OBAFEMI AWOLOWO UNIVERSITY IS NOT} OFFERING TO ITS STUDENTS AS SPECIAL ELECTIVES.
1. GST 123
2. GST 123:
3. GST 113:
4. GST 222:
Communication in French
Communication in Arabic
Nigerian Peoples and Culture
5. GST
112:
Peace Studies and Conflict Resolution
Logic Philosophy and Human Existence

\section{NUC COURSES THAT HAVE PEACE EDUCATION CONTENTS THAT ARE NOT OFFERED IN OBAFEMI AWOLOWO UNIVERSITY \\ GST 113: Nigerian Peoples and Culture (2 Units)}

This course is $100 \%$ peace education as it touches on several elements of peace education like: multicultural education in the topics like 'Study of Nigerian history', culture and arts in pre-colonial times', Nigerian's perception of his world', Culture areas of Nigeria and their characteristics': some topics also focus on future education in the topics like 'Concepts of trade', 'Economic self-reliance': A topic in environmental education could also be filtered out i.e. 'Re-orientation of moral Environmental problems.'

\section{GST 222: Peace Studies and Conflict Resolution (2 Units)}

This course epitomises peace education, as some of the topics emphasize Basic Concepts in peace studies while some others revolves conflict resolution. Topics like 'Peace as vehicle of unity and development, Conflict issues, Types of conflict, e. g. Ethnic/religious/political/economic conflicts, Root causes of conflicts and violence in Africa, Indigene/settler phenomenon, etc. These are all at the centre of peace education.

The researcher shall now examine the degree of peace education diet in NUC recommended General Studies and Obafemi Awolowo University Special Electives to discover what OAU students are missing out on 'Peace Diet' because of Obafemi Awolowo University's departure from NUC Benchmark 
Table 4.3 Quantifying PED in NUC Benchmark and OAU special electives Curriculum PED IN NUC BENCHMARK GENERAL STUDIES

\begin{tabular}{|c|c|c|c|c|c|c|c|c|c|c|c|c|}
\hline 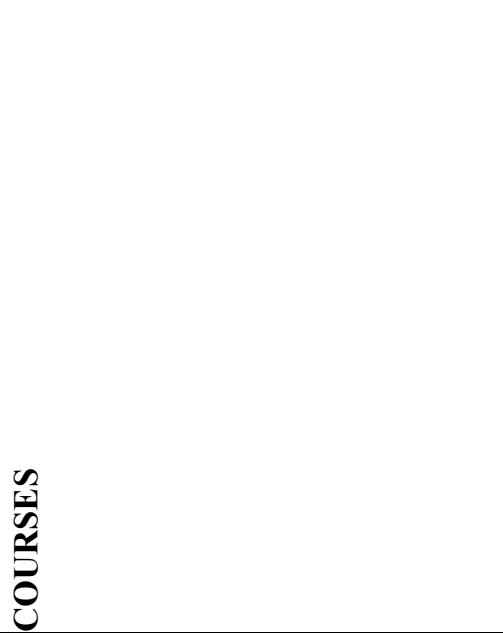 & 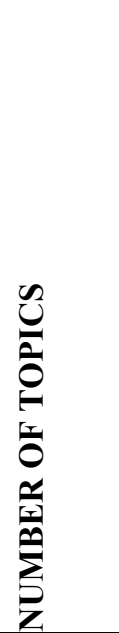 & 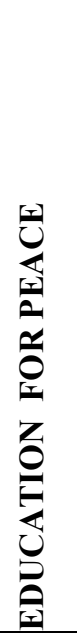 & 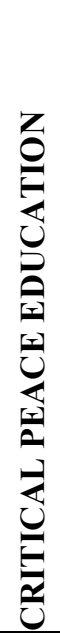 & 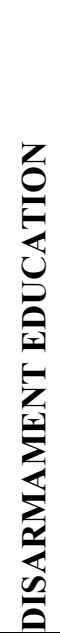 & 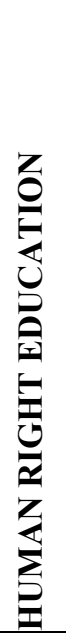 & 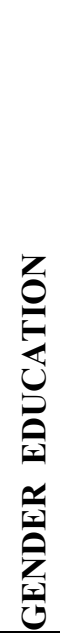 & 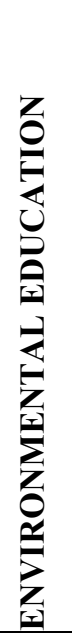 & 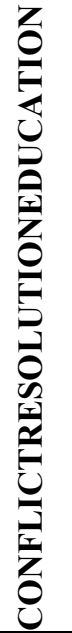 & 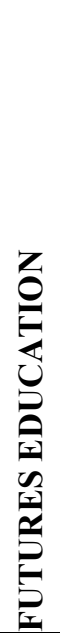 & 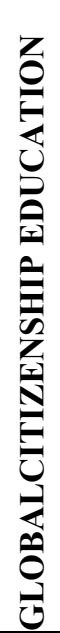 & 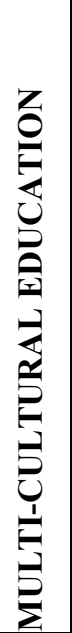 & 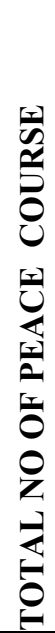 \\
\hline Communication in English & 8 & -- & -- & -- & -- & -- & -- & -- & 8 & -- & -- & 8 \\
\hline $\begin{array}{l}\text { Logic Philosophy and Human } \\
\text { Existence }\end{array}$ & 11 & -- & -- & -- & -- & -- & -- & -- & 1 & -- & -- & 1 \\
\hline Nigerian Peoples and Culture & 13 & 2 & -- & -- & 1 & -- & 1 & -- & 3 & -- & 6 & 13 \\
\hline $\begin{array}{l}\text { Use of Library, Study Skills and } \\
\text { Information Communication } \\
\text { Technology (ICT) }\end{array}$ & 17 & -- & -- & -- & -- & -- & -- & -- & 6 & -- & -- & 6 \\
\hline Communication in English II & 7 & 1 & -- & -- & -- & -- & -- & -- & 6 & -- & -- & 7 \\
\hline Communication in French & 5 & -- & -- & -- & -- & -- & -- & -- & -- & -- & -- & -- \\
\hline Communication in Arabic & 4 & -- & -- & -- & -- & -- & -- & -- & -- & -- & -- & -- \\
\hline History and Philosophy of Science & 12 & -- & -- & -- & -- & -- & 3 & -- & -- & -- & -- & 3 \\
\hline $\begin{array}{l}\text { Peace Studies and Conflict } \\
\text { Resolution }\end{array}$ & 15 & 8 & -- & -- & -- & -- & -- & 6 & -- & -- & 1 & 15 \\
\hline $\begin{array}{l}\text { Introduction to Entrepreneurial } \\
\text { Skills }\end{array}$ & 12 & -- & -- & -- & -- & -- & -- & -- & 9 & -- & -- & 9 \\
\hline TOTAL & 104 & 11 & -- & -- & 1 & -- & 4 & 6 & 33 & -- & 7 & 62 \\
\hline PERCENTAGE TOTAL & $59.3 \%$ & 10.5 & -- & -- & 0.9 & -- & 3.8 & 5.7 & 31.7 & -- & 6.7 & \\
\hline \multicolumn{13}{|c|}{ PED IN OAU SPECIAL ELECTIVE COURSES } \\
\hline $\begin{array}{l}\text { SEO 001: Fundamentals of Human } \\
\text { Behaviour }\end{array}$ & 6 & -- & -- & -- & -- & -- & -- & -- & 2 & -- & -- & 2 \\
\hline $\begin{array}{llll}\text { SEO 002: Man and His } \\
\text { Environment }\end{array}$ & 2 & -- & -- & -- & -- & -- & 1 & -- & -- & -- & 1 & 2 \\
\hline $\begin{array}{l}\text { SEO 003: Principles and Practices } \\
\text { of Entrepreneurship and Self } \\
\text { Employment }\end{array}$ & 11 & -- & -- & -- & -- & -- & -- & -- & 4 & -- & -- & 4 \\
\hline $\begin{array}{l}\text { SEO 004: Business Environment } \\
\text { and Approach to Business Start Up }\end{array}$ & 8 & -- & -- & -- & -- & -- & -- & -- & 1 & -- & -- & 1 \\
\hline SER 001: The Use of English & 4 & -- & -- & -- & -- & -- & -- & -- & -- & -- & -- & -- \\
\hline $\begin{array}{l}\text { SER 002: Humanity and African } \\
\text { Experience }\end{array}$ & 10 & -- & -- & -- & -- & -- & -- & -- & -- & -- & 5 & 5 \\
\hline SEP 001: Drug and Society I & 9 & -- & -- & -- & -- & -- & -- & -- & 1 & -- & -- & 1 \\
\hline SEP 002: Drug and Society II & 16 & -- & -- & -- & -- & -- & 1 & -- & 2 & -- & -- & 3 \\
\hline SED 001: Poverty and Health & 9 & -- & -- & -- & -- & -- & 2 & -- & -- & 1 & -- & 3 \\
\hline SEH 001: Man and His Health & 7 & -- & -- & -- & -- & -- & -- & -- & 2 & -- & -- & 2 \\
\hline $\begin{array}{l}\text { SEH 002: Community Health and } \\
\text { Man's Behaviour }\end{array}$ & 7 & -- & -- & -- & -- & -- & 1 & -- & 1 & -- & -- & 2 \\
\hline $\begin{array}{l}\text { SES002: Man and His Biological } \\
\text { World }\end{array}$ & 3 & -- & -- & -- & -- & -- & -- & -- & -- & -- & -- & -- \\
\hline SEL 001: Introduction to Law & 20 & -- & -- & -- & 3 & 1 & -- & -- & -- & -- & -- & 4 \\
\hline
\end{tabular}




\begin{tabular}{|c|c|c|c|c|c|c|c|c|c|c|c|c|}
\hline $\begin{array}{l}\text { SEL 002: Introduction to Legal } \\
\text { Constitution And Processes }\end{array}$ & 8 & -- & -- & -- & -- & -- & -- & -- & -- & -- & -- & -- \\
\hline $\begin{array}{l}\text { SEE 001: Indigenous Education in } \\
\text { Nigeria }\end{array}$ & 7 & 2 & -- & -- & -- & -- & -- & -- & -- & -- & 1 & 3 \\
\hline $\begin{array}{l}\text { SEE 002: Introduction to Nigerian } \\
\text { Education }\end{array}$ & 9 & 1 & -- & -- & -- & -- & -- & -- & -- & -- & 5 & 6 \\
\hline $\begin{array}{l}\text { SEM 001: Fundamentals in } \\
\text { Building and Design for Human } \\
\text { Habitation }\end{array}$ & 17 & -- & -- & -- & -- & -- & -- & -- & -- & -- & -- & -- \\
\hline $\begin{array}{l}\text { SEM 002: Issues in Land } \\
\text { Management }\end{array}$ & 13 & -- & -- & -- & -- & -- & -- & -- & -- & -- & -- & -- \\
\hline $\begin{array}{l}\text { SEA 001: Government and } \\
\text { Administration of Public Sector }\end{array}$ & 5 & -- & -- & -- & -- & -- & -- & -- & -- & -- & -- & -- \\
\hline $\begin{array}{l}\text { SEA 002: Elements of Business } \\
\text { Administration }\end{array}$ & 11 & -- & -- & -- & -- & -- & -- & -- & -- & -- & -- & -- \\
\hline $\begin{array}{l}\text { SEG 001: Food Production and the } \\
\text { Nation }\end{array}$ & 5 & -- & -- & --- & -- & -- & 1 & -- & -- & -- & -- & 1 \\
\hline $\begin{array}{l}\text { SEG 002: Agriculture and Human } \\
\text { Survival }\end{array}$ & 2 & -- & -- & -- & -- & -- & -- & -- & -- & -- & 1 & 1 \\
\hline SET 002: Technology and Society & 5 & -- & -- & -- & -- & -- & -- & -- & -- & -- & -- & -- \\
\hline LIB 001: The Use of Library & 7 & -- & -- & -- & -- & -- & -- & -- & 2 & -- & -- & 2 \\
\hline TOTAL & 201 & 3 & -- & -- & 3 & 1 & 6 & -- & 15 & 1 & 13 & 42 \\
\hline PEPERCENTAGE TOTAL & $20.3 \%$ & 1.4 & $\begin{array}{l}-- \\
- \\
-\end{array}$ & -- & 1.4 & 0.4 & 2.9 & -- & 7.4 & 0.4 & 6.4 & \\
\hline
\end{tabular}

Table 4.4: Percentage of PED in NUC General Courses and OAU Special Electives

\begin{tabular}{|l|l|l|l|}
\hline S/N & $\begin{array}{l}\text { ELEMENT OF PEACE } \\
\text { EDUCATION }\end{array}$ & $\begin{array}{l}\text { \% IN NUC BENCH MARK } \\
\text { GNS COURSES }\end{array}$ & $\begin{array}{l}\text { IN OAU SPECIAL } \\
\text { ELECTIVES }\end{array}$ \\
\hline 1. & Education For Peace (E4P) & $10.5 \%$ & $1.4 \%$ \\
\hline 2. & Critical Peace Education(CPE) & -- & -- \\
\hline 3. & Disarmament Education (DE) & -- & -- \\
\hline 4. & Human Right Education (HRE) & $0.9 \%$ & $1.4 \%$ \\
\hline 5. & Gender Education (GE) & -- & $0.4 \%$ \\
\hline 6. & Environmental Education(EE) & $3.8 \%$ & $2.9 \%$ \\
\hline 7. & $\begin{array}{l}\text { Conflict Resolution Education } \\
\text { (CRE) }\end{array}$ & $5.7 \%$ & -- \\
\hline 8. & Futures Education(FE) & $31.7 \%$ & $7.4 \%$ \\
\hline 9. & $\begin{array}{l}\text { Global Citizenship Education } \\
\text { GCE) }\end{array}$ & -- & $0.4 \%$ \\
\hline 10. & Multi-cultural Education (ME) & $6.7 \%$ & $6.4 \%$ \\
\hline TOTAL & & $\mathbf{5 9 . 3 \%}$ & $\mathbf{2 0 . 3 \%}$ \\
\hline
\end{tabular}


FIG 4.1: The Proportion Peace Education Elements in NUC GNS Courses and OAU Special Elective Courses.

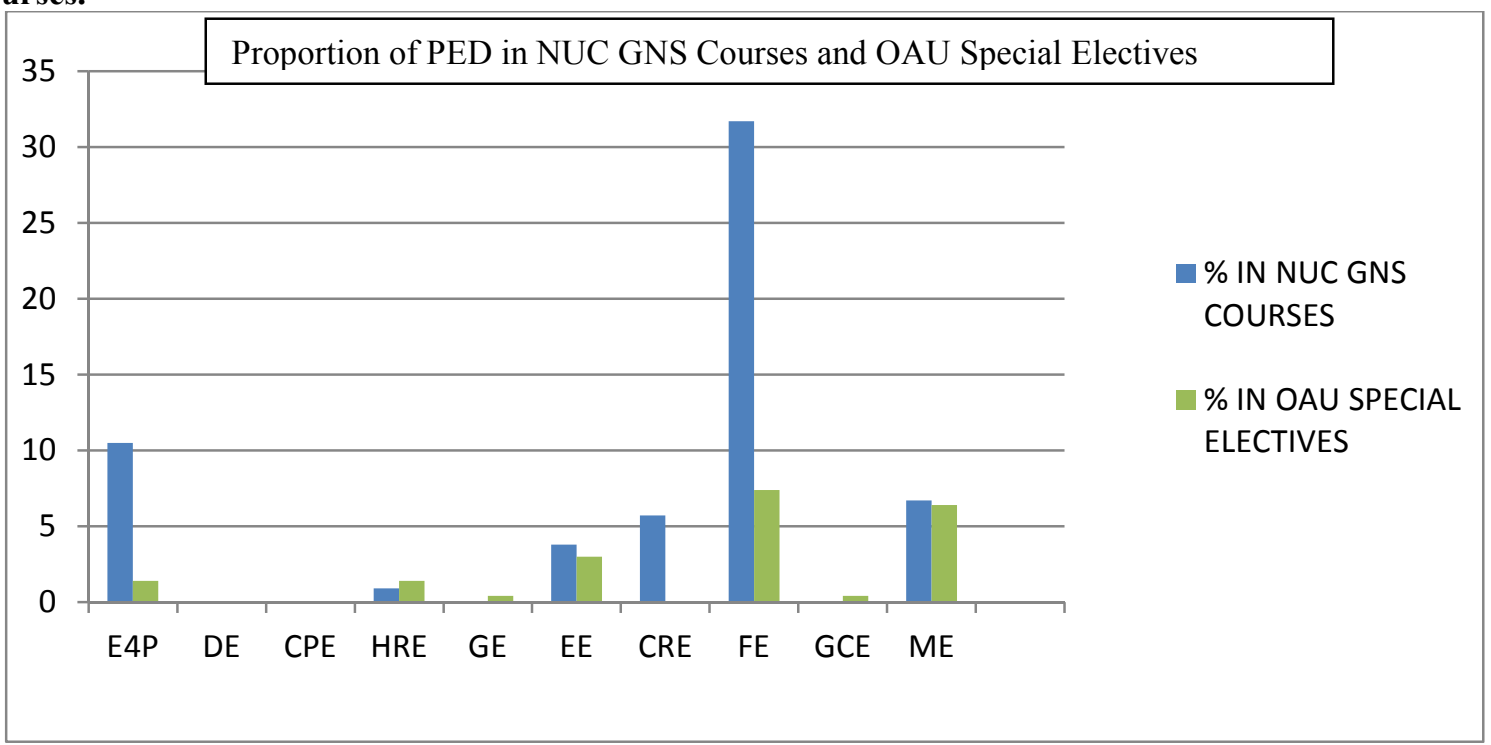

From the table 4.3 and 4.4 presented above, NUC recommended only 10 general courses with 104 topics having $59.3 \%$ in all the topics added together. Future education has the highest percentage of peace education i.e. $31.7 \%$, followed by education for peace which possesses $10.5 \%$ while human right education has the least percentage i.e. $0.9 \%$. OAU on the other hand offers 24 Special Elective courses. all the topics added together is 201 having the total percentage of $20.3 \%$, however future education has $7.4 \%$ which happens to be the highest, followed by multi-cultural education which is $6.4 \%$, while the possessors of the least percentage are gender education and global citizenship education which is $0.4 \%$.

From fig.1. Presented above, it could be concluded that OAU curriculum for special electives tend a little bit towards multicultural and environmental education as it has the highest proportion, but relatively with little or no proportion at all in education for peace and conflict resolution. Dwelling on this view however, Integrative Theory of Peace Education posits that, "Nothing short of a comprehensive, all-inclusive and sustained curriculum of education for peace could possibly alter the current attitudes and worldviews that contribute so greatly to conflict, violence and war afflicting human societies worldwide." Therefore, the $20.3 \%$ of peace education elements in all the 201 topics in the OAU special elective curriculum may not be enough to suppress the culture of war that students have so long imbibe since birth because of its relatively little or no attention paid to Education for Peace and Confliction Resolution Education.

\subsection{THE QUANTITY OF PEACE EDUCATION IN OAU SPECIAL ELECTIVES}

At this juncture we shall evaluate OAU Special Elective courses by taking its topics one after another to determine elements related to peace education in it.

Table 4.5: PED in SEO 001 (Fundamentals of Human Behaviour)

\begin{tabular}{|l|l|l|}
\hline S/N & TOPICS & PEACE EDUCATION DIET(PED) \\
\hline 1 & The basics of human perception & $\bullet$ NIL \\
\hline 2 & Memory capacity and organization & $\bullet$ NIL \\
\hline 3 & The development of skill and expertise & $\bullet \quad$ Future education \\
\hline 4 & The characteristics of everyday reasoning & $\bullet \quad$ Future education \\
\hline 5 & Decision making & $\bullet \quad$ NIL \\
\hline 6 & Information systems & \\
\hline
\end{tabular}

Peace Education Diet in SEO 001 is 33.3\%

Table 4.6: PED in SEO 002 (Man and His Environment)

\begin{tabular}{|c|c|c|}
\hline $\mathbf{S} / \mathbf{N}$ & TOPICS & PEACE EDUCATION DIET (PED) \\
\hline 1. & students are taken to a natural environment & $\begin{array}{ll} & \text { Environmental education, } \\
\text { - } & \text { Multi-cultural education } \\
\end{array}$ \\
\hline 2. & Government's failure to take care of natural Environment & - $\quad$ Environmental education \\
\hline
\end{tabular}

Peace Education Diet in SEO 002 is 100\% 
Table 4.7: PED in SEO 003 (Principles and Practices of Entrepreneurship and Self Employment)

\begin{tabular}{|c|c|c|}
\hline $\mathbf{S} / \mathbf{N}$ & TOPICS & PEACE EDUCATION DIET (PED) \\
\hline 1. & Business opportunity defined & $\bullet \quad$ NIL \\
\hline 2. & Characteristics of business opportunity & - NIL \\
\hline 3. & Distinctions between ideas and business opportunity & - NIL \\
\hline 4. & $\begin{array}{l}\text { The process of generating screening and selection of venture } \\
\text { ideas }\end{array}$ & - Future education \\
\hline 5. & The entrepreneurial decision & - Future education \\
\hline 6. & MIAR framework for key success & - NIL \\
\hline 7. & Key success factors in setting up a small business. & - Future education \\
\hline 8. & Procedures for setting up and managing one's business & - Future education \\
\hline 9. & Meaning and scope of enterprise & - NIL \\
\hline 10. & Different forms of enterprise & - NIL \\
\hline 11. & Roles of entrepreneur in business & - NIL \\
\hline
\end{tabular}

Peace Education Diet in SEO 003 is $36.3 \%$

Table 4.8: PED in SEO 004 (Business Environment and Approach to Business Start Up)

\begin{tabular}{|l|l|c|}
\hline S/N & TOPICS & PEACE EDUCATION DIET (PED) \\
\hline 1. & Business plan defined & $\bullet$ NIL \\
\hline 2. & Why write business plan? & $\bullet$ NIL \\
\hline 3. & When is business plan written? & $\bullet$ NIL \\
\hline 4. & What are the types of business plan? & $\bullet$ Future education \\
\hline 5. & How is a business plan written? & $\bullet$ \\
\hline 6. & What does a business plan looks like? & $\bullet$ \\
\hline 7. & How is a business plan organized? & $\bullet$ \\
\hline 8. & The standard business plan format & NIL \\
\hline
\end{tabular}

Peace Education Diet in SEO 004 is $12.5 \%$

Table 4.9: PED in SER 001 (Use of English)

\begin{tabular}{|l|l|c|}
\hline S/N & TOPICS & PEACE EDUCATION DIET (PED) \\
\hline 1. & Reading & $\bullet$ NIL \\
\hline 2. & Writing & $\bullet \quad$ NIL \\
\hline 3. & Listening & $\bullet \quad$ NIL \\
\hline 4. & Speaking & $\bullet \quad$ NIL \\
\hline
\end{tabular}

Peace Education Diet in SER 001 is 0\%

Table 4.10: PED in SER 002 (Humanity and African Experience)

\begin{tabular}{|c|c|c|}
\hline $\mathbf{S} / \mathbf{N}$ & TOPICS & PEACE EDUCATION DIET (PED) \\
\hline 1. & The pre-colonial African political system & • Multi-cultural education \\
\hline 2. & Economic development in colonial Africa & - $\quad$ NIL \\
\hline 3. & Colonial rule and social change in Africa & - $\quad$ NIL \\
\hline 4. & Post-colonial Africa's political and economic development & - $\quad$ NIL \\
\hline 5. & Religious and social change in Africa & - $\quad$ Multicultural education \\
\hline 6. & $\begin{array}{l}\text { The colonial experience and form of literature in } \\
\text { contemporary Africa }\end{array}$ & - Multi-cultural education \\
\hline 7. & Function and significance of African art & - $\quad$ NIL \\
\hline 8. & The features of African music and theatre & - NIL \\
\hline 9. & The concept of context and functions of tradition in Africa & - $\quad$ Multicultural education \\
\hline 10. & Popular culture in contemporary Africa & - $\quad$ Multicultural education \\
\hline
\end{tabular}

Peace Education Diet in SER 002 is 50\% 
Table 4.11: PED in SEP 001 (Drug and Society I)

\begin{tabular}{|l|l|l|}
\hline S/N & TOPICS & PEACE EDUCATION DIET (PED) \\
\hline 1. & Encouraging appropriate drug use in the society & $\bullet$ NIL \\
\hline 2. & Types of irrational prescribing & $\bullet$ \\
\hline 3. & Rational drug dispensing & $\bullet$ \\
\hline 4. & Rational use of drug by patients & $\bullet$ NIL \\
\hline 5. & Patient education & $\bullet \quad$ Future education \\
\hline 6. & Evaluation of rational drug use & $\bullet \quad$ NIL \\
\hline 7. & Core interventions to promote more rational use of medicine & $\bullet \quad$ NIL \\
\hline 8. & Patient feedback & $\bullet$ \\
\hline 9. & Pharmaco-vigilance & NIL \\
\hline
\end{tabular}

Peace Education Diet in SEP 001 is $11.1 \%$

Table 4.12: PED in SEP 002 (Drug and Society II)

\begin{tabular}{|c|c|c|}
\hline $\mathbf{S} / \mathbf{N}$ & TOPICS & PEACE EDUCATION DIET (PED) \\
\hline 1. & Pharmacy law and control drugs & $\bullet \quad$ NIL \\
\hline 2. & An overview of drug abuse, misuse and disuse & - $\quad$ NIL \\
\hline 3. & Conditions that predisposes people to drug abuse & - NIL \\
\hline 4. & Common symptoms of drug abuse & - $\quad$ NIL \\
\hline 5. & Problems with drug abuse & - NIL \\
\hline 6. & Drugs misuse & - NIL \\
\hline 7. & Some examples of common drug misuse & - NIL \\
\hline 8. & Why do people misuse & - NIL \\
\hline 9. & Effects of drug misuse & - NIL \\
\hline 10. & Problems associated with drug disuse & - NIL \\
\hline 11. & Why drug maybe disused & - NIL \\
\hline 12. & The human environment and toxic chemicals & - $\quad$ Environmental education \\
\hline 13. & Emergency management of poisoning & - $\quad$ Future education \\
\hline 14. & Home measure-( first aid) & $\bullet \quad$ NIL \\
\hline 15. & Types of toxic mushrooms & $\bullet \quad$ NIL \\
\hline 16. & Management of mushroom poisoning & - $\quad$ Future education \\
\hline
\end{tabular}

Peace Education Diet in SEP 002 is $18.7 \%$

Table 4.13: PED in SED 001 (Poverty and Health)

\begin{tabular}{|l|l|l|}
\hline S/N & TOPICS & PEACE EDUCATION DIET (PED) \\
\hline 1. & Definition of poverty and its measurement & $\bullet \quad$ NIL \\
\hline 2. & Eradication of poverty & $\bullet \quad$ NIL \\
\hline 3. & Achieving universal pre-education & $\bullet \quad$ NIL \\
\hline 4. & Reducing child mortality & $\bullet \quad$ NIL \\
\hline 5. & Improving material health & $\bullet \quad$ Environmental education \\
\hline 6. & Eradication of disease especially on materials & $\bullet \quad$ Environmental education \\
\hline 7. & Achieving environmental sustainability & $\bullet \quad$ Global citizenship education \\
\hline 8. & Global partnership & $\bullet$ \\
\hline 9. & Poverty analysis & NIL \\
\hline
\end{tabular}

Peace Education Diet in SED 001 is 33.3\% 
Table 4.14: PED in SEH 001 (Man and His Health)

\begin{tabular}{|l|l|c|}
\hline S/N & TOPICS & PEACE EDUCATION DIET (PED) \\
\hline 1. & Basic concepts of health & $\bullet$ \\
\hline 2. & Causes of road accident & $\bullet$ \\
\hline 3. & preventions of road accident & $\bullet$ \\
\hline 4. & Medical emergencies and first aid & $\bullet \quad$ Future education \\
\hline 5. & Common medical emergencies in Nigeria & $\bullet \quad$ NIL \\
\hline 6. & Basic life support & $\bullet \quad$ NIL \\
\hline 7. & First aid & $\bullet \quad$ Future education \\
\hline
\end{tabular}

Peace Education Diet in SEH 001 is $28.5 \%$

Table 4.15: PED in SEH 002 (Community Health and Man's Behaviour)

\begin{tabular}{|l|l|c|}
\hline S/N & TOPICS & PEACE EDUCATION DIET (PED) \\
\hline 1. & Impacts of human activities on the environment & $\bullet \quad$ Environmental education \\
\hline 2. & Industrial development & $\bullet \quad$ NIL \\
\hline 3. & Pollution defined & $\bullet \quad$ NIL \\
\hline 4. & Sustainable development & $\bullet \quad$ Nuture education \\
\hline 5. & Immunization and immunity & $\bullet \quad$ NIL \\
\hline 6. & Contraindication to vaccination & $\bullet$ \\
\hline 7. & The burden of oral diseases & NIL \\
\hline
\end{tabular}

Peace Education Diet in SEH 002 is $28.5 \%$

Table 4.16: PED in SES 002 (Man and His Biological World)

\begin{tabular}{|l|l|c|}
\hline S/N & TOPICS & PEACE EDUCATION DIET (PED) \\
\hline 1. & A brief history of biochemistry & $\bullet \quad$ NIL \\
\hline 2. & A brief history of Microbiology & $\bullet \quad$ NIL \\
\hline 3. & A brief history of Botany & $\bullet \quad$ NIL \\
\hline
\end{tabular}

Peace Education Diet in SES 002 is $0 \%$

Table 4.17: PED in SEL 001 (Introduction to Law)

\begin{tabular}{|c|c|c|}
\hline $\mathbf{S} / \mathbf{N}$ & TOPICS & PEACE EDUCATION DIET (PED) \\
\hline 1. & Meaning and scope of law & $\bullet \quad$ NIL \\
\hline 2. & A brief constitutional history of Nigeria & - $\quad$ NIL \\
\hline 3. & Definition of democracy & - $\quad$ NIL \\
\hline 4. & Features of democracy & - $\quad$ NIL \\
\hline 5. & Challenges of Nigerian democracy & - $\quad$ NIL \\
\hline 6. & Strategies for the challenges of democracies & - $\quad$ NIL \\
\hline 7. & Nigerian security problem and probable solutions & - $\quad$ NIL \\
\hline 8. & Concept of human right & - Human right education \\
\hline 9. & $\begin{array}{l}\text { Relevant provisions of the } 1999 \text { constitution for their } \\
\text { protection }\end{array}$ & - $\quad$ NIL \\
\hline 10. & Definition of scope of contract & - $\quad$ NIL \\
\hline 11. & Definition of criminal law & - $\quad$ NIL \\
\hline 12. & Elements of an office & - $\quad$ NIL \\
\hline 13. & Aim of criminal punishment & - NIL \\
\hline 14. & Is death penalty justified? & - $\quad$ NIL \\
\hline 15. & Concept of eutenacia & - NIL \\
\hline 16. & Meaning and scope of international law & - $\quad$ NIL \\
\hline 17. & Importance and relevance of international law & - $\quad$ NIL \\
\hline 18. & What are human's right? & - $\quad$ Human right education \\
\hline 19. & Effects of female genital mutilation & - $\quad$ Gender education \\
\hline 20. & $\begin{array}{l}\text { Objectives of UNO, ICC, African chapter on human and } \\
\text { people's right }\end{array}$ & - Human right education \\
\hline
\end{tabular}

Peace Education Diet in SEL 001 is 20\% 
Table 4.18: PED in SEL 002 (Introduction to Legal Constitution and Processes)

\begin{tabular}{|l|l|c|}
\hline S/N & TOPICS & PEACE EDUCATION DIET (PED) \\
\hline 1. & What is election? & $\bullet \quad$ NIL \\
\hline 2. & Functions of election democratic society & $\bullet \quad$ NIL \\
\hline 3. & Problems of election in democratic society & $\bullet \quad$ NIL \\
\hline 4. & Types of election in democratic society & $\bullet \quad$ NIL \\
\hline 5. & Meaning and features of electoral act 2006 as amended & $\bullet \quad$ NIL \\
\hline 6. & Solutions to electoral problems in Nigeria & $\bullet \quad$ NIL \\
\hline 7. & Judicial proceeding in the Nigeria electoral society & $\bullet$ \\
\hline 8. & $\begin{array}{l}\text { Adjudicatory systems in Nigeria before 1954, between 1954 } \\
\text { and 1963, between and 2007 }\end{array}$ \\
\hline
\end{tabular}

Peace Education Diet in SEL 002 is $0 \%$

Table 4.19: PED in SEE 001 (Indigenous Education)

\begin{tabular}{|l|l|l|}
\hline S/N & TOPICS & PEACE EDUCATION DIET (PED) \\
\hline 1. & Indigenous vs. western education & $\bullet$ \\
\hline 2. & Indigenous knowledge and education & $\bullet$ \\
\hline 3. & Models of indigenous education & $\bullet$ \\
\hline 4. & Methods of Indigenous education & $\bullet$ \\
\hline 5. & Roles of indigenous education in individual transformation & $\bullet$ \\
\hline 6. & Importance of indigenous education & $\bullet$ \\
\hline 7. & Attitudes, norms, and values of indigenous people & $\bullet$ NIL \\
\hline & & $\bullet$ Mucation for peace \\
\hline
\end{tabular}

Peace Education Diet in SEE 001 is $42.8 \%$

Table 4.20: PED in SEE 002 (Introduction to Nigerian Education)

\begin{tabular}{|c|c|c|}
\hline $\mathbf{S} / \mathbf{N}$ & TOPICS & PEACE EDUCATION DIET (PED) \\
\hline 1. & The historical development of western education in Nigeria & $\bullet \quad$ NIL \\
\hline 2. & Indigenous moral education in Nigeria & - $\quad$ Education for peace \\
\hline 3. & Indigenous civil administration & - $\quad$ Multi-cultural education \\
\hline 4. & Nigeria indigenous and economic system & - $\quad$ Multi-cultural education \\
\hline 5. & The meaning and purpose of traditional education in Nigeria & - $\quad$ NIL \\
\hline 6. & $\begin{array}{l}\text { Oral transmission of knowledge in Nigerian folklore, motes, } \\
\text { ethics and idioms }\end{array}$ & - Multi-cultural education \\
\hline 7. & Political system in traditional societies & - $\quad$ Multi-cultural education \\
\hline 8 & Language diversification in Nigeria & - $\quad$ Multi-cultural education \\
\hline 9. & Overview of Nigerian educational policy & NIL \\
\hline
\end{tabular}

Peace Education Diet in SEE 002 is $66.6 \%$

Table 4.21: PED in SEM 001 (Fundamentals in Building and Design for Human Habitation)

\begin{tabular}{|c|c|c|}
\hline $\mathbf{S} / \mathbf{N}$ & TOPICS & PEACE EDUCATION DIET (PED) \\
\hline 1. & Importance of building & $\bullet \quad$ NIL \\
\hline 2. & Factors and elements of grown environment & - NIL \\
\hline 3. & Building as a communal effort & - NIL \\
\hline 4. & Construction industries in Nigeria & - NIL \\
\hline 5. & Industrial construction works & - $\quad$ NIL \\
\hline 6. & People and subsectors in the construction industry & - NIL \\
\hline 7. & Professionals in construction & - NIL \\
\hline 8. & $\begin{array}{l}\text { The building process and questions that activates the mind in } \\
\text { the inception of a project }\end{array}$ & - $\quad$ NIL \\
\hline 9. & Types of contract in building & NIL \\
\hline 10. & Methods of building & - $\quad$ NIL \\
\hline 11. & Functions of the participants & - $\quad$ NIL \\
\hline 12. & Common sanitary appliances in the building & - NIL \\
\hline 13. & Active and passive controls & NIL \\
\hline
\end{tabular}




\begin{tabular}{|l|l|c|}
\hline S/N & TOPICS & PEACE EDUCATION DIET (PED) \\
\hline 14. & Electrical services in building & $\bullet$ NIL \\
\hline 15. & Economic forces and physical development & $\bullet$ \\
\hline 16. & Sources of moisture & $\bullet \quad$ NIL \\
\hline 17. & Functions of system & $\bullet \quad$ NIL \\
\hline
\end{tabular}

Peace Education Diet in SEM 001 is $0 \%$

Table 4.22: PED in SEM 002 (Issues in Land Management)

\begin{tabular}{|c|c|c|}
\hline $\mathbf{S} / \mathbf{N}$ & TOPICS & PEACE EDUCATION DIET (PED) \\
\hline 1. & Estate management as an academic discipline & $\bullet \quad$ NIL \\
\hline 2. & The concept of land & - $\quad$ NIL \\
\hline 3. & Distinguishing characteristics of land & - $\quad$ NIL \\
\hline 4. & Astarte attributes of land & - $\quad$ NIL \\
\hline 5. & Economic significance of land & - $\quad$ NIL \\
\hline 6. & Land as an exhaustible and inexhaustible resources & - $\quad$ NIL \\
\hline 7. & Permanence and safety & - $\quad$ NIL \\
\hline 8. & Supply and demand for land & - $\quad$ NIL \\
\hline 9. & Factors influencing the use of land resources & - $\quad$ NIL \\
\hline 10 & The land tenure system in Nigeria & - $\quad$ NIL \\
\hline 11. & Property development & - $\quad$ NIL \\
\hline 12. & Objectives of development & - $\quad$ NIL \\
\hline 13. & Sale and lease back & - $\quad$ NIL \\
\hline
\end{tabular}

Peace Education Diet in SEM 002 is $0 \%$

Table 4.23: PED in SEA 001 (Government and Administration of Public Sector)

\begin{tabular}{|c|c|c|}
\hline $\mathbf{S} / \mathbf{N}$ & TOPICS & PEACE EDUCATION DIET (PED) \\
\hline 1. & $\begin{array}{l}\text { Public administration as an organization of government } \\
\text { policies }\end{array}$ & $\bullet \quad$ NIL \\
\hline 2. & Public administration as an academic discipline & - $\quad$ NIL \\
\hline 3. & Public administration and civil servants & NIL \\
\hline 4. & Public administration and its functions & NIL \\
\hline
\end{tabular}

Peace Education Diet in SEA 001 is $0 \%$

Table 4.24: PED in SEA 002 (Elements of Business Administration)

\begin{tabular}{|l|l|c|}
\hline S/N & TOPICS & PEACE EDUCATION DIET (PED) \\
\hline 1. & The nature and scope of accounting & $\bullet$ NIL \\
\hline 2. & The functions of accounting & $\bullet$ NIL \\
\hline 3. & $\begin{array}{l}\text { Accounting and its relationship with information system of } \\
\text { organization }\end{array}$ & $\bullet$ \\
\hline 4. & Accounting procedures and system & $\bullet$ \\
\hline 5. & Double entry book-keeping systems NIL \\
\hline 6. & Profit and loss accounting and balance sheet of a sale trader & $\bullet \quad$ NIL \\
\hline 7. & $\begin{array}{l}\text { Accounting treatment of control accounts and bank } \\
\text { reconciliation }\end{array}$ & $\bullet$ \\
\hline 8. & The account of non-profit oriented organizations \\
\hline 9. & $\begin{array}{l}\text { Receipt and payment versus income and expenditure } \\
\text { accounts }\end{array}$ & $\bullet$ \\
\hline 10. & Incomplete records NIL \\
\hline 11. & Specialized transactions & $\bullet$ \\
\hline
\end{tabular}

Peace Education Diet in SEA 002 is $0 \%$ 
Table 4.25: PED in SEG 001 (Food Production and the Nation)

\begin{tabular}{|l|l|l|}
\hline S/N & TOPICS & PEACE EDUCATION DIET (PED) \\
\hline 1. & The need for progress in agriculture & $\bullet$ \\
\hline 2. & The roles of agriculture & $\bullet$ \\
\hline 3. & Managing the ecosystem & $\bullet$ \\
\hline 4. & Agriculture as a form of energy & $\bullet \quad$ NIL \\
\hline 5. & Animal protein versus plant protein & $\bullet \quad$ NIL \\
\hline
\end{tabular}

Peace Education Diet in SEG 001 is $20 \%$

Table 4.26: PED in SEG 002 (Agriculture and Human Survival)

\begin{tabular}{|l|l|c|}
\hline S/N & TOPICS & PEACE EDUCATION DIET (PED) \\
\hline $\mathbf{1 .}$ & Field trip & $\bullet \quad$ Multi-cultural education \\
\hline $\mathbf{2 .}$ & Agro product and Human Survival & $\bullet \quad$ NIL \\
\hline
\end{tabular}

Peace Education Diet in SEG 002 is $50 \%$

Table 4.27: PED in SET 002 (Technology and Society)

\begin{tabular}{|l|l|c|}
\hline S/N & TOPICS & PEACE EDUCATION DIET (PED) \\
\hline 1. & Economics and technological development & $\bullet \quad$ NIL \\
\hline 2. & Government funding for new technology & $\bullet$ \\
\hline 3. & Technology and Economics in the Future & $\bullet \quad$ NIL \\
\hline 4. & Techno capitalism & $\bullet$ \\
\hline 5. & $\begin{array}{l}\text { Sociological factors and effects; Values, Institutions and } \\
\text { groups, International, Environment. }\end{array}$ & \\
\hline
\end{tabular}

Peace Education Diet in SET 002 is $0 \%$

Table 4.28: PED in LIB 001 (The Use of Library)

\begin{tabular}{|c|c|c|}
\hline $\mathbf{S} / \mathbf{N}$ & TOPICS & PEACE EDUCATION DIET (PED) \\
\hline 1. & Library services & $\bullet \quad$ NIL \\
\hline 2. & Types of library and their various functions & - $\quad$ NIL \\
\hline 3. & The organization set up of library & - NIL \\
\hline 4. & Technical processing of a library materials & - $\quad$ Future education \\
\hline 5. & Cataloguing & - $\quad$ Future education \\
\hline 6. & Reference tools and services & - NIL \\
\hline 7. & Preservation of library materials & - $\quad$ NIL \\
\hline
\end{tabular}

Peace Education Diet in LIB 001 is $28.5 \%$

Table 4.29: PERCENTAGE OF PEACE EDUCATION DIET IN OAU SPECIAL ELECTIVES COURSES

\begin{tabular}{|l|l|l|l|}
\hline S/N & SPECIAL ELECTIVES COURSES & $\begin{array}{l}\text { NUMBER OF TOPICS } \\
\text { WITH PED }\end{array}$ & $\begin{array}{l}\text { NUMBER } \\
\text { TOPICS }\end{array}$ \\
\hline 1. & SEO 001: Fundamentals of Human Behaviour & 2 & 6 \\
\hline 2. & SEO 002: Man and His Environment Priples And Practices Of & 4 & 2 \\
\hline 3. & $\begin{array}{l}\text { SEO 003: Principles } \\
\text { Entrepreneurship And Self Employment }\end{array}$ & 2 & 11 \\
\hline 4. & $\begin{array}{l}\text { SEO 004: Business Environment And Approach To } \\
\text { Business Start Up }\end{array}$ & 1 & 8 \\
\hline 5. & SER 001: The Use Of English & 0 & 4 \\
\hline 6. & SER 002: Humanity And African Experience & 5 & 10 \\
\hline 7. & SEP 001: Drug And Society I & 1 & 9 \\
\hline 8. & SEP 002: Drug And Society II & 3 & 16 \\
\hline 9. & SED 001: Poverty And Health & 3 & 9 \\
\hline 10. & SEH 001: Man And His Health & 2 & 7 \\
\hline 11. & SEH 002: Community Health And Man's Behaviour & 2 & 3 \\
\hline 12. & SES 002: Man And His Biological World & 0 & 20 \\
\hline 13. & SEL 001: Introduction To Law & 4 & \\
\hline
\end{tabular}




\begin{tabular}{|l|l|l|l|}
\hline S/N & SPECIAL ELECTIVES COURSES & $\begin{array}{l}\text { NUMBER OF TOPICS } \\
\text { WITH PED }\end{array}$ & $\begin{array}{l}\text { NUMER } \\
\text { TOPICS }\end{array}$ \\
\hline 14. & $\begin{array}{l}\text { SEL 002: Introduction Legal Constitution And } \\
\text { Processes }\end{array}$ & 0 & 8 \\
\hline 15. & SEE 001: Indigenous Education & 3 & 7 \\
\hline 16. & SEE 002: Introduction To Nigerian Education & 6 & 9 \\
\hline 17. & $\begin{array}{l}\text { SEM 001: Fundamentals Of Building And Design } \\
\text { For Human Habitation }\end{array}$ & 0 & 17 \\
\hline 18. & SEM 002: Issues In Land Management & 0 & 13 \\
\hline 19. & $\begin{array}{l}\text { SEA 001: Government And Administration Of } \\
\text { Public Sector }\end{array}$ & 0 & 5 \\
\hline 20. & SEA 002: Elements Of Business Administration & 0 & 11 \\
\hline 21. & SEG 001: Food Production And The Nation & 1 & 5 \\
\hline 22. & SEG 002: Agriculture And Human Survival & 1 & 2 \\
\hline 23. & SET 002: Technology And Society & 0 & 5 \\
\hline 24. & LIB 001: The Use of Library & 2 & 7 \\
\hline
\end{tabular}

$42 / 201 \times 100 / 1=42 / 201=20.8 \%$

FIG 4.2: Proportion of PED topics in OAU Special Electives

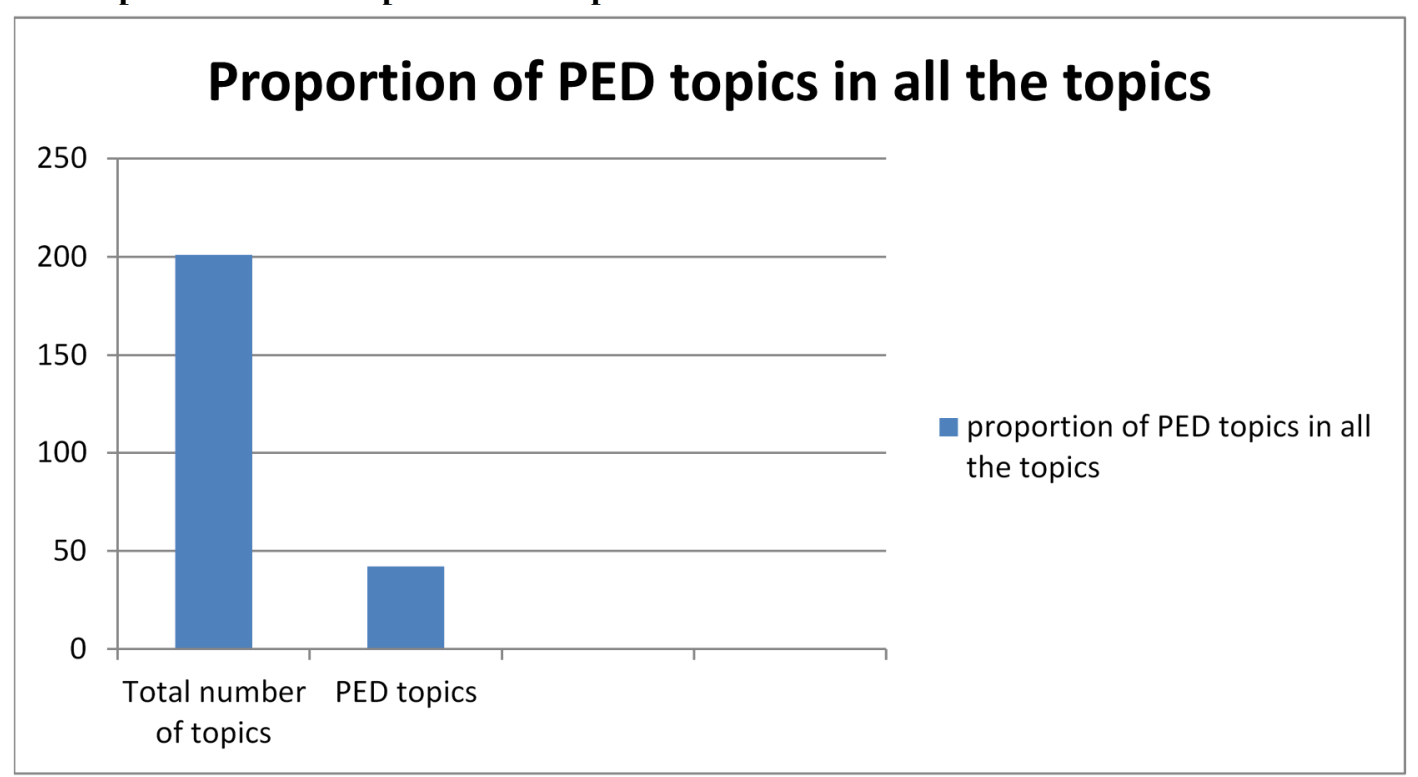

From the result shown in the table above, the total number of all the Special Elective courses offered in OAU is 201 with only 42 topics relating to peace education, thereby amounting to $20.8 \%$ of peace diet in the school curriculum. It is also worthy of note that almost $80 \%$ of the 42 topics tend towards "future education" and "multicultural education". Therefore the $20.8 \%$ of peace diet in the total of 201 topics in the OAU Special Elective course is too low; hence, the peace reservoir of OAU students may be too small to make them peaceful citizens.

\subsection{THE QUANTITY OF PEACE EDUCATION IN FACULTY COURSES IN OAU}

In dealing with this research question, we shall start to evaluate the topics in each compulsory course depending on the number of compulsory/general courses made available by each faculty to determine the quantity of peace education element in them.

\section{Faculty of Administration}

This faculty offers 2 general courses and these are:

- $\quad$ SSC 101: Man and his Social Environment

- SSC I02 : Wealth and Poverty of Nations 
Table 4.30: PED in SSC 101 (Man and his Social Environment)

\begin{tabular}{|l|l|r|}
\hline S/N & TOPICS & PEACE EDUCATION DIET (PED) \\
\hline 1. & Social Institutions & $\bullet \quad$ NIL \\
\hline 2. & Socio-Cultural Processes & $\bullet \quad$ Environmental education \\
\hline 3. & Ethnic Problems & $\bullet \quad$ NIL \\
\hline 4. & Social Change & $\bullet \quad$ NIL \\
\hline 5. & Social Problems & $\bullet \quad$ NIL \\
\hline 6. & Forms of Social Structure & $\bullet \quad$ NIL \\
\hline 7. & Concept of Sociology & $\bullet \quad$ NIL \\
\hline 8. & Origin of Sociology & $\bullet \quad$ NIL \\
\hline 9. & Concepts in Sociology & \\
\hline
\end{tabular}

Peace Education Diet in SSC 101 is $11.1 \%$

Table 4.31: PED in SSC 102 (Wealth and Poverty of Nations)

\begin{tabular}{|l|l|l|}
\hline S/N & TOPICS & PEACE EDUCATION DIET (PED) \\
\hline 1. & Definition of Economics & $\bullet$ NIL \\
\hline 2. & $\begin{array}{l}\text { Explanations and Illustration of concepts in the } \\
\text { Definition }\end{array}$ & $\bullet$ NIL \\
\hline 3. & Goals of Nigerian market economic & $\bullet \quad$ NIL \\
\hline 4. & Microeconomics tools & $\bullet \quad$ NIL \\
\hline 5. & Monetary policy and fiscal Policy & \\
\hline
\end{tabular}

Peace Education Diet in SSC 102 is $0 \%$

2. Faculty of Agriculture

This faculty offer 3 general course and these are:

- AAE 201: Introduction to Agriculture economics

- AXD 201: Introduction to rural Sociology

- AXD 202 : Organization of village communities

Table 4.32: PED in AAE 201 (Introduction to Agriculture economics)

\begin{tabular}{|l|l|c|}
\hline S/N & TOPICS & PEACE EDUCATION DIET (PED) \\
\hline 1. & Scope and Method of agriculture economics & $\bullet$ \\
\hline 2. & $\begin{array}{l}\text { Price theory and the functions of market with particular } \\
\text { reference to Agriculture }\end{array}$ & $\bullet$ \\
\hline 3. & Theories of Agricultural production & $\bullet \quad$ NIL \\
\hline 4. & Cost Analysis with reference to Agricultural production & $\bullet \quad$ NIL \\
\hline 5. & Theory of Distribution & \\
\hline
\end{tabular}

Peace Education Diet in AAE 201 is $0 \%$

Table 4.33: PED in AXD 201 (Introduction to rural Sociology)

\begin{tabular}{|c|c|c|}
\hline $\mathbf{S} / \mathbf{N}$ & TOPICS & PEACE EDUCATION DIET (PED) \\
\hline 1. & Definition of rural sociology & $\bullet \quad$ NIL \\
\hline 2. & Importance of the study of rural sociology & - $\quad$ NIL \\
\hline 3. & Socialization and the rural social organization & - $\quad$ NIL \\
\hline 4. & Major social institutions & - NIL \\
\hline 5. & Rural social values and norms & $\begin{array}{ll}\text { - } & \text { multi-cultural education } \\
\text { - } & \text { education for peace }\end{array}$ \\
\hline 6. & Diffusion of innovations & - NIL \\
\hline 7. & Social processes & - NIL \\
\hline 8. & $\begin{array}{l}\text { Nature and characteristics of cooperation, competition, } \\
\text { acculturation, accommodation, assimilation of culture }\end{array}$ & $\begin{array}{ll}\text { - } & \text { Education for peace } \\
\text { - } & \text { Multi-cultural education }\end{array}$ \\
\hline
\end{tabular}

Peace Education Diet in AXD 201 is $25 \%$ 
Table 4.34: PED in AXD 202 (Organization of village communities)

\begin{tabular}{|c|c|c|}
\hline $\mathbf{S} / \mathbf{N}$ & TOPICS & PEACE EDUCATION DIET (PED) \\
\hline 1. & Village organization of major ethnic groups in Nigeria & - Multi-cultural education \\
\hline 2. & Social groups and associations & - NIL \\
\hline 3. & Leadership in rural communities & - NIL \\
\hline 4. & $\begin{array}{l}\text { Characteristics, types, functions of leaders in rural development } \\
\text { and extension works }\end{array}$ & - NIL \\
\hline 5. & Definition of rural community leaders & - $\quad$ NIL \\
\hline 6. & Organization for rural development in Nigeria & - $\quad$ NIL \\
\hline 7. & Ingredients for area development and growth attitude of people & - NIL \\
\hline 8. & Natural resources and institutions & - $\quad$ Environmental education \\
\hline 9. & Rural industrialist ion & - NIL \\
\hline 10 & Mobilizing community people for development & - $\quad$ Future education \\
\hline
\end{tabular}

3. Faculty of Art

This faculty offer 2 general course and these are:

- EGL 101 - English Language

- $\quad$ LIT 101 - Introduction to Fiction

\begin{tabular}{|l|l|c|}
\hline S/N & TOPICS & PEACE EDUCATION DIET (PED) \\
\hline 1. & Basic concepts in English & $\bullet$ NIL \\
\hline 2. & $\begin{array}{l}\text { The destruction between 'language' and "a } \\
\text { language" }\end{array}$ & $\bullet$ NIL \\
\hline 3. & $\begin{array}{l}\text { The destruction between grammar and other } \\
\text { levels of analysis }\end{array}$ & $\bullet$ NIL \\
\hline 4. & $\begin{array}{l}\text { The English sentences introduced through the } \\
\text { concepts of basis simple sentences pattern }\end{array}$ & $\bullet$ NIL \\
\hline
\end{tabular}

Peace Education Diet in EGL 101 is 0\%

Table 4.36: PED in LIT 101 (Introduction to Fiction)

\begin{tabular}{|l|l|c|}
\hline S/N & TOPICS & PEACE EDUCATION DIET (PED) \\
\hline 1. & $\begin{array}{l}\text { An introductory course to literary languages and } \\
\text { to the organizing principles of techniques of } \\
\text { fiction through selected short stories and novels. }\end{array}$ & \\
\hline
\end{tabular}

Peace Education Diet in LIT 101 is $0 \%$

\section{Faculty of Education}

This faculty offer 6 general courses and these are:

- EDU 101 - Introduction to the Teaching profession

- EDU 102 - Principles and practice of Education

- $\quad$ EFC 203 - Psychological foundation of Education

- $\quad$ EFC 202 - Philosophical foundations of education

- DET 202 - Technology of Education

- $\quad$ SEC 202 - Curriculum and Instruction

- $\quad$ EFC 301 - Guidance and Counselling

- $\quad$ EFC 303 - Test and Measurement

- EFC 413 - Sociology of Education

- EAP 402- Educational Administration 
Table 4.37: PED in EDU 101 (Introduction to teaching profession)

\begin{tabular}{|c|c|c|}
\hline $\mathbf{S} / \mathbf{N}$ & TOPICS & PEACE EDUCATION DIET (PED) \\
\hline 1. & $\begin{array}{l}\text { Professionalization: The united business of teacher } \\
\text { education }\end{array}$ & $\bullet \quad$ NIL \\
\hline 2. & Concept of teaching & - $\quad$ NIL \\
\hline 3. & Concept of learning & - $\quad$ NIL \\
\hline 4. & Ethics of teaching & $\begin{array}{ll}\text { - } & \text { Education for peace } \\
\text { - } & \text { Future education } \\
\end{array}$ \\
\hline 5. & Trade unionism in the teaching profession in Nigeria & - NIL \\
\hline 6. & Professionalization in Education & - $\quad$ NIL \\
\hline 7. & Teacher education: roles, curriculum and competence & - $\quad$ Future education \\
\hline 8. & Other professions helping teachers to achieve class goals & - NIL \\
\hline 9. & Instructional methods in classroom & - $\quad$ NIL \\
\hline 10. & The use of instructional materials for effective teaching & - $\quad$ NIL \\
\hline 11. & Examination malpractice in Nigerian Education system & - $\quad$ NIL \\
\hline 12. & The roles of teachers in community and nation building & - $\quad$ Future education \\
\hline
\end{tabular}

Peace Education Diet in EDU 101 is 12\%

Table 4.38: PED in EDU 102 (Principles and practice of Education)

\begin{tabular}{|l|l|l|}
\hline S/N & TOPICS & PEACE EDUCATION DIET (PED) \\
\hline 1. & The contexts of National policy on education & $\bullet \quad$ NIL \\
\hline 2. & Concepts, aims and objectives of education & $\bullet \quad$ NIL \\
\hline 3. & The growth of modern education in Nigeria & $\bullet \quad$ NIL \\
\hline 4. & Principles of motivation & $\bullet \quad$ NIL \\
\hline 5. & Organogram of the school system & $\bullet \quad$ NIL \\
\hline 6. & The 6-3-3-4 system of Education & $\bullet \quad$ Multi-cultural education \\
\hline 7. & Traditional education (origin, content and method) & $\bullet \quad$ NIL \\
\hline 8. & Teaching the teachers the principles of teaching and learning & $\bullet$ \\
\hline 9. & Purpose and method of assessment & $\bullet$ \\
\hline 10. & Teacher and the school & NIL \\
\hline
\end{tabular}

Peace Education Diet in EDU 102 is $10 \%$

Table 4.39: PED in EFC 203 (Psychological foundation of Education)

\begin{tabular}{|l|l|r|}
\hline S/N & TOPICS & PEACE EDUCATION DIET (PED) \\
\hline 1. & The concept of psychology & $\bullet \quad$ NIL \\
\hline 2. & Branches of psychology & $\bullet \quad$ NIL \\
\hline 3. & Definition of Educational psychology & $\bullet \quad$ NIL \\
\hline 4. & Data collection in Educational psychology & $\bullet \quad$ NIL \\
\hline 5. & The concepts of growth and development & $\bullet \quad$ Multi-cultural education \\
\hline 6. & Individual differences & $\bullet \quad$ NIL \\
\hline 7. & Some theories of learning & $\bullet$ \\
\hline 8. & Mental Health (teacher and students) & $\bullet$ \\
\hline 9. & Transfer of learning & $\bullet$ \\
\hline 10. & Remembering & $\bullet$ \\
\hline 11. & Forms of memory & $\bullet$ \\
\hline 12. & Classroom management & Future education \\
\hline
\end{tabular}

Peace Education Diet in EFC 203 is 16.6\% 
Table 4.40: PED in EFC 202 (Philosophical foundations of education)

\begin{tabular}{|l|l|c|}
\hline S/N & TOPICS & PEACE EDUCATION DIET (PED) \\
\hline 1. & Meaning and purpose of philosophy & $\bullet$ NIL \\
\hline 2. & Definition of philosophy of education & $\bullet$ \\
\hline 3. & Naturalism: meaning and advocates of Naturalism & $\bullet$ \\
\hline 4. & Idealism: meaning and advocates of idealism & $\bullet \quad$ NIL \\
\hline 5. & Realism: meaning and advocates of realism & $\bullet \quad$ NIL \\
\hline 6. & Pragmatism: meaning and advocates of pragmatism & $\bullet$ \\
\hline 7. & Existentialism meaning advocates of existentialism & NIL \\
\hline 8. & Concept of teaching & $\bullet$ NIL \\
\hline 9. & Play in education & $\bullet$ \\
\hline 10. & Disbelief in classroom introduction & $\bullet$ \\
\hline 11. & Democratic Education & NIL \\
\hline
\end{tabular}

Peace Education Diet in EFC 202 is 9\%

Table 4.41: PED in DET 202 (Technology of Education)

\begin{tabular}{|l|l|l|}
\hline S/N & TOPICS & PEACE EDUCATION DIET (PED) \\
\hline 1. & Overview of education technology & $\bullet$ NIL \\
\hline 2. & Importance of education technology & $\bullet$ \\
\hline 3. & Problem and prospect of education technology & $\bullet$ NIL \\
\hline 4. & Curriculum and education technology & $\bullet \quad$ NIL \\
\hline 5. & Psychological foundation of education technology & $\bullet \quad$ Education for peace \\
\hline 6. & System approach to education & $\bullet \quad$ NIL \\
\hline 7. & Instructional materials and media & $\bullet$ \\
\hline 8. & Criteria for evaluating instructional material & $\bullet$ \\
\hline 9. & Instructional methods & $\bullet$ \\
\hline 10. & Technologies in education & NIL \\
\hline
\end{tabular}

Peace Education Diet in DET 202 is 10\%

Table 4.42: PED in SEC 202 (Curriculum and Instruction)

\begin{tabular}{|l|l|l|}
\hline S/N & TOPICS & PEACE EDUCATION DIET (PED) \\
\hline 1. & Concepts in education & $\bullet$ NIL \\
\hline 2. & Curriculum and its types & $\bullet$ NIL \\
\hline 3. & Curriculum and instruction & $\bullet$ NIL \\
\hline 4. & Communication & $\bullet$ NIL \\
\hline 5. & Teaching methods & $\bullet$ NIL \\
\hline 6. & Instructional methods & $\bullet \quad$ NIL \\
\hline 7. & The syllabus & $\bullet \quad$ NIL \\
\hline 8. & The skim of work & $\bullet$ Future education \\
\hline 9. & Lesson plan & \\
\hline
\end{tabular}

Peace Education Diet in SEC 202 is $11.1 \%$

Table 4.43: PED in EFC 301 (Guidance and Counselling)

\begin{tabular}{|l|l|l|}
\hline S/N & TOPICS & PEACE EDUCATION DIET (PED) \\
\hline 1. & Definition of guidance and counseling & $\bullet$ \\
\hline 2. & Goals of guidance & $\bullet$ \\
\hline 3. & $\begin{array}{l}\text { Types of counseling: personal, educational, vocational, health, } \\
\text { psychological etc. }\end{array}$ & $\bullet$ \\
\hline 4. & Need for educational guidance and counseling & $\bullet$ \\
\hline 5. & School counseling & $\bullet$ \\
\hline 6. & Counseling processes & $\bullet$ \\
\hline 7. & $\begin{array}{l}\text { The roles of school counselors in the effective implementation } \\
\text { of the 6-3-3-4 system of education in Nigeria }\end{array}$ \\
\hline
\end{tabular}

Peace Education Diet in EFC 301 is $0 \%$ 
Table 4.44: PED in EFC 303 (Test and Measurement)

\begin{tabular}{|l|l|c|}
\hline S/N & TOPICS & PEACE EDUCATION DIET (PED) \\
\hline 1. & Test and Measurement defined & $\bullet$ NIL \\
\hline 2. & $\begin{array}{l}\text { Categorization of test on the basis of unit, purpose, point of } \\
\text { reference of testing }\end{array}$ & $\bullet$ NIL \\
\hline 3. & Qualities of a good test & $\bullet$ NIL \\
\hline 4. & Types of validity & $\bullet \quad$ NIL \\
\hline 5. & Factors associated with test & $\bullet$ \\
\hline 6. & Reliability & $\bullet$ \\
\hline 7. & Item difficulty index & $\bullet$ \\
\hline 8. & Distracter analysis & $\bullet$ \\
\hline 9. & The test blue print & NIL \\
\hline 10. & Test administration & $\bullet$ \\
\hline 11. & Test scoring & $\bullet$ \\
\hline 12. & Test reporting & NIL \\
\hline
\end{tabular}

Peace Education Diet in EFC 303 is 0\%

Table 4.45: PED in EFC 413 (Sociology of Education)

\begin{tabular}{|l|l|r|}
\hline S/N & TOPICS & PEACE EDUCATION DIET (PED) \\
\hline 1. & Sociology defined & $\bullet \quad$ NIL \\
\hline 2. & Concepts in sociology & $\bullet \quad$ NIL \\
\hline 3. & Theories of deviant & $\bullet \quad$ NIL \\
\hline 4. & Types of deviant & $\bullet \quad$ NIL \\
\hline 5. & Social mobility & $\bullet \quad$ NIL \\
\hline 6. & Social control & $\bullet \quad$ NIL \\
\hline 7. & Social stratification & $\bullet \quad$ NIL \\
\hline 8. & Social class & $\bullet \quad$ NIL \\
\hline 9. & Differentiation in school & $\bullet \quad$ Multi-cultural education \\
\hline 10. & Social change & \\
\hline 11. & Schooling and societies across cultures & \\
\hline
\end{tabular}

Peace Education Diet in EFC 413 is $18.1 \%$

Table 4.46: PED in EAP 402 (Educational Administration)

\begin{tabular}{|l|l|l|}
\hline S/N & TOPICS & PEACE EDUCATION DIET (PED) \\
\hline 1. & The concept of management in education & $\bullet$ NIL \\
\hline 2. & Principles and processes of school management & $\bullet$ NIL \\
\hline 3. & Functions of management & $\bullet$ NIL \\
\hline 4. & Principles of management & $\bullet$ NIL \\
\hline 5. & School discipline & $\bullet$ Education for peace \\
& & $\bullet \quad$ Future education \\
\hline 6. & Communication & $\bullet$ \\
\hline 7. & Instructional management & $\bullet$ \\
\hline 8. & Policy procedures and rules & $\bullet$ \\
\hline 9. & Record keeping & $\bullet \quad$ NIL \\
\hline 10. & Some issues in schools accountability \\
\hline
\end{tabular}

Peace Education Diet in EAP 402 is 20\%

5. Faculty of Environmental Design and Management

This faculty offers only 1 general course and this is:

- ARC 103 - Graphics communication 
Table 4.47: PED in ARC 103 (Graphics communication)

\begin{tabular}{|l|l|l|}
\hline S/N & TOPICS & $\begin{array}{l}\text { PEACE EDUCATION DIET } \\
\text { (PED) }\end{array}$ \\
\hline 1. & Introduction to basic drawing techniques and conventions & $\bullet \quad$ NIL \\
\hline 2. & Presentation tools and techniques & $\bullet \quad$ NIL \\
\hline 3. & Drawing tools and materials & $\bullet \quad$ NIL \\
\hline 4. & The presentation of common views & $\bullet$ NIL \\
\hline 5. & Oblique and perspective views & $\bullet \quad$ NIL \\
\hline 6. & Lettering & $\bullet$ NIL \\
\hline
\end{tabular}

6. Faculty of Law

This faculty offer 4 general course and these are:

- PUL 101 - Nature and function of Law

- PUL 102 - Sources of Law

- PUL 201 - Introduction to Constitution

- PUL 202- Military and Constitution Making in Nigeria

Table 4.48: PED in PUL 101 (Nature and function of Law)

\begin{tabular}{|l|l|c|}
\hline S/N & TOPICS & $\begin{array}{l}\text { PEACE EDUCATION DIET } \\
\text { (PED) }\end{array}$ \\
\hline 1. & Aspects of law & $\bullet$ NIL \\
\hline 2. & $\begin{array}{l}\text { Types of law-eternal law, Devine law, natural law and human positive } \\
\text { law }\end{array}$ & $\bullet$ NIL \\
\hline 3. & Methods of social control through law & $\bullet \quad$ Education for peace \\
\hline 4. & Legal reasoning and Approach to problems & $\bullet \quad$ NIL \\
\hline 5. & Legal reasoning in judicial processes & $\bullet \quad$ NIL \\
\hline 6. & Legal reasoning in legislation & NIL \\
\hline
\end{tabular}

Peace Education Diet in PUL101 is $16.6 \%$

Table 4.49: PED in PUL 102 (Sources of Law)

\begin{tabular}{|l|l|c|}
\hline S/N & TOPICS & PEACE EDUCATION DIET (PED) \\
\hline 1. & Uses of source materials & $\bullet$ NIL \\
\hline 2. & Law library and legal research & $\bullet$ NIL \\
\hline 3. & Legal writing & $\bullet$ NIL \\
\hline
\end{tabular}

Peace Education Diet in PUL102 is $0 \%$

\begin{tabular}{|c|c|c|}
\hline $\mathbf{S} / \mathbf{N}$ & TOPICS & $\begin{array}{l}\text { PEACE EDUCATION DIET } \\
\text { (PED) }\end{array}$ \\
\hline 1. & Definition Constitutional law & $\bullet \quad$ NIL \\
\hline 2. & Sources of constitutional law & - $\quad$ NIL \\
\hline 3. & $\begin{array}{l}\text { The concept of separation of power, rule of law, federalism, } \\
\text { supremacy of constitution or parliament }\end{array}$ & - $\quad$ NIL \\
\hline 4. & $\begin{array}{l}\text { Constitutional history of Nigeria from the advent of British rule up- } \\
\text { to-data }\end{array}$ & - NIL \\
\hline
\end{tabular}

Peace Education Diet in PUL 201 is $0 \%$

Table 4.51: PED in PUL 202 (Military and Constitution Making in Nigeria)

\begin{tabular}{|c|c|c|}
\hline $\mathbf{S} / \mathbf{N}$ & TOPICS & PEACE EDUCATION DIET (PED) \\
\hline 1. & Law making by the military & $\bullet \quad$ NIL \\
\hline 2. & The executive under military & - NIL \\
\hline 3. & The military and the search for constitutional order & - $\quad$ NIL \\
\hline 4. & The supremacy of constitution & - $\quad$ NIL \\
\hline 5. & Legislative power & - NIL \\
\hline 6. & Judicial power & - $\quad$ NIL \\
\hline 7. & Executive power & - $\quad$ NIL \\
\hline
\end{tabular}

Peace Education Diet in PUL 202 is $0 \%$ 


\section{Faculty of Pharmacy}

This faculty offer 3 general course and these are:

- $\quad$ PHA 201 - Introductory Pharmaceutics

- $\quad$ PHA 301 - Liquid and Semi Solid Dosage Forms

- $\quad$ PHA 401 - Solid dosage forms

Table 4.52: PED in PHA 201 (Introductory Pharmaceutics)

\begin{tabular}{|l|l|c|}
\hline S/N & TOPICS & PEACE EDUCATION DIET (PED) \\
\hline 1. & Pharmaceutical calculations & $\bullet \quad$ NIL \\
\hline 2. & Introductory unit operations & $\bullet \quad$ NIL \\
\hline 3. & Introduction to disperse system & $\bullet \quad$ NIL \\
\hline 4. & Emulsions, suspension, gel and aerosols & $\bullet \quad$ NIL \\
\hline 5. & Introduction to solid dosage forms & \\
\hline
\end{tabular}

Peace Education Diet in PHA 201 is $0 \%$

Table 4.53: PED in PHA 301 (Liquid and Semi Solid Dosage Forms)

\begin{tabular}{|l|l|c|}
\hline S/N & TOPICS & $\begin{array}{l}\text { PEACE EDUCATION DIET } \\
\text { (PED) }\end{array}$ \\
\hline 1. & Fundamental properties of disperse system & $\bullet \quad$ NIL \\
\hline 2. & Miscelle and miscellisation & $\bullet$ \\
\hline 3. & Emulsions, formulations and evaluation & $\bullet$ \\
\hline 4. & $\begin{array}{l}\text { Suspensions }- \text { NIL } \\
\text { evaluations }\end{array}$ & $\bullet \quad$ NIL \\
\hline 5. & Semi solid systems in pharmacy preparations and & $\bullet \quad$ NIL \\
\hline 6. & Types, properties, preparations and performances of evaluation & $\bullet \quad$ NIL \\
\hline
\end{tabular}

Peace Education Diet in PHA 301 is $0 \%$

Table 4.54: PED in PHA 401 (Solid Dosage Forms)

\begin{tabular}{|l|l|c|}
\hline S/N & TOPICS & PEACE EDUCATION DIET (PED) \\
\hline 1. & Properties of the solid state & $\bullet$ NIL \\
\hline 2. & Micrometrics & $\bullet \quad$ NIL \\
\hline 3. & Tabletting & $\bullet \quad$ NIL \\
\hline 4. & Capsules & $\bullet \quad$ NIL \\
\hline
\end{tabular}

Peace Education Diet in PHA 401 is $0 \%$

8. Faculty of Social Sciences

This faculty offer 2 general course and these are:

- SSC 103 - Man and Environment Relations

- $\quad$ SSC 112 - Foundation of Psychology

Table 4.55: PED in SSC 103 (Man and Environment Relations)

\begin{tabular}{|c|c|c|}
\hline $\mathbf{S} / \mathbf{N}$ & TOPICS & PEACE EDUCATION DIET (PED) \\
\hline 1. & $\begin{array}{l}\text { The influences of environment on man's } \\
\text { economic, social and cultural patterns }\end{array}$ & • $\quad$ Environmental education \\
\hline 2. & $\begin{array}{l}\text { Human's ecology and man's utilization of } \\
\text { environmental resources }\end{array}$ & - $\quad$ Environmental education \\
\hline 3. & $\begin{array}{l}\text { Environmental deterioration resulting from the } \\
\text { impact of man }\end{array}$ & - $\quad$ Environmental education \\
\hline 4. & $\begin{array}{l}\text { The effect of population growth, economics and } \\
\text { social policies, political activities and modern } \\
\text { technology on environmental deterioration }\end{array}$ & - $\quad$ Environmental education \\
\hline
\end{tabular}

Peace Education Diet in SSC 103 is 100\% 
Table 4.56: PED in SSC 112 (Foundation of Psychology)

\begin{tabular}{|l|l|c|}
\hline S/N & TOPICS & $\begin{array}{l}\text { PEACE EDUCATION } \\
\text { DIET (PED) }\end{array}$ \\
\hline 1. & $\begin{array}{l}\text { Sources of Psychological information, research literature experimental } \\
\text { data field of observational studies }\end{array}$ & $\bullet$ NIL \\
\hline 2. & Location and interpretation of psychological information & $\bullet \quad$ NIL \\
\hline 3. & $\begin{array}{l}\text { Nomenclatures of psychology: organization of brief psychological } \\
\text { reports. }\end{array}$ & $\bullet \quad$ NIL \\
\hline
\end{tabular}

Peace Education Diet in SSC 112 is 0\%

9. Faculty of Basic Medical Science

10. Faculty of Clinical Science

11. Faculty of Dentistry

12. Faculty of Sciences

13. Faculty of Technology

All the 5 faculties listed above pass through the same compulsory courses which happen to be dispensed from the faculty of sciences. There are 4 compulsory courses for these faculties:

- $\quad$ ZOO 101 - Introductory zoology

- PHY 101 - General physics I

- $\quad$ PHY 102 - General physics II

- $\quad$ MTH 101 - Elementary mathematics

Table 4.57: PED in ZOO 101 (Introductory zoology)

\begin{tabular}{|l|l|c|}
\hline S/N & TOPICS & PEACE EDUCATION DIET (PED) \\
\hline 1. & Introduction to concept in ecology & $\bullet$ NIL \\
\hline 2. & Definition of ecology & $\bullet$ NIL \\
\hline 3. & Introductory genetics & $\bullet$ NIL \\
\hline 4. & Historical development of science of genetics & $\bullet$ NIL \\
\hline 5. & Introductory physiology & $\bullet \quad$ NIL \\
\hline 6. & Introductory vertebrate biology & \\
\hline
\end{tabular}

Peace Education Diet in ZOO 101 is $0 \%$

Table 4.58: PED in PHY 101 (General physics I)

\begin{tabular}{|l|l|c|}
\hline S/N & TOPICS & PEACE EDUCATION DIET (PED) \\
\hline 1. & Fundamental principles of mechanics, & $\bullet$ NIL \\
\hline 2. & $\begin{array}{l}\text { Mechanical properties of matter including } \\
\text { elasticity, surface tension and viscosity }\end{array}$ & $\bullet$ NIL \\
\hline 3. & Mechanical waves & $\begin{array}{l}\text { NIL } \\
\text { Thermal physics - thermal, properties including } \\
4 .\end{array}$ \\
\hline
\end{tabular}

Peace Education Diet in PHY 101 is 0\%

Table 4.59: PED in PHY 102 (General physics II)

\begin{tabular}{|c|c|c|}
\hline $\mathbf{S} / \mathbf{N}$ & TOPICS & PEACE EDUCATION DIET (PED) \\
\hline 1. & $\begin{array}{l}\text { Fundamental laws of electricity and magnetism } \\
\text { and their applications }\end{array}$ & $\bullet \quad$ NIL \\
\hline 2. & $\begin{array}{l}\text { Electron physics - introduction to physics of } \\
\text { electronics and some applications }\end{array}$ & - $\quad$ NIL \\
\hline 3. & $\begin{array}{l}\text { Optics: principles and applications of geometrical } \\
\text { and physical optics. }\end{array}$ & - NIL \\
\hline
\end{tabular}

Peace Education Diet in PHY 102 is 0\%

Table 4.60: PED in MTH 101 (Elementary Mathematics)

\begin{tabular}{|l|l|c|}
\hline S/N & TOPICS & PEACE EDUCATION DIET (PED) \\
\hline 1. & Mathematical techniques & $\bullet$ NIL \\
\hline 2. & Fundamentals of mathematical processes & $\bullet \quad$ NIL \\
\hline
\end{tabular}

Peace Education Diet in MTH 101 is $0 \%$ 
Table 4.61: Quantity of PED in Combined Faculty Courses

\begin{tabular}{|c|c|c|c|c|}
\hline $\mathbf{S} / \mathbf{N}$ & FACULTY & $\begin{array}{l}\text { NUMBER } \\
\text { TOPICS }\end{array}$ & $\begin{array}{lr}\text { NUMBER } & \text { OF } \\
\text { TOPICS } & \text { WITH } \\
\text { PED } & \end{array}$ & PERCENTAGE \\
\hline 1. & Faculty of Administration & 14 & 1 & 7.1 \\
\hline 2. & Faculty of Agriculture & 23 & 5 & 21.7 \\
\hline 3. & Faculty of Art & 5 & -- & -- \\
\hline 4. & Faculty of Education & 104 & 13 & 12.5 \\
\hline 5. & $\begin{array}{l}\text { Faculty of Environmental Design } \\
\text { and Management(EDM) }\end{array}$ & 6 & -- & -- \\
\hline 6. & Faculty of Law & 20 & 1 & 5 \\
\hline 7. & Faculty of Pharmacy & 15 & -- & -- \\
\hline 8. & Faculty of Social Sciences & 7 & 4 & 57.1 \\
\hline 9. & $\begin{array}{lll}\text { Faculty of } & \text { Basic } & \text { Medical } \\
\text { Science(BMS) } & & \end{array}$ & 14 & -- & -- \\
\hline 10. & Faculty of Clinical Science & 14 & -- & -- \\
\hline 11. & Faculty of Dentistry & 14 & -- & -- \\
\hline 12. & Faculty of Sciences & 14 & -- & -- \\
\hline 13. & Faculty of Technology & 14 & -- & -- \\
\hline \multicolumn{2}{|c|}{ TOTAL } & 264 & 24 & $9 \%$ \\
\hline
\end{tabular}

FIG 4.3: Proportion of PED in Faculty Courses

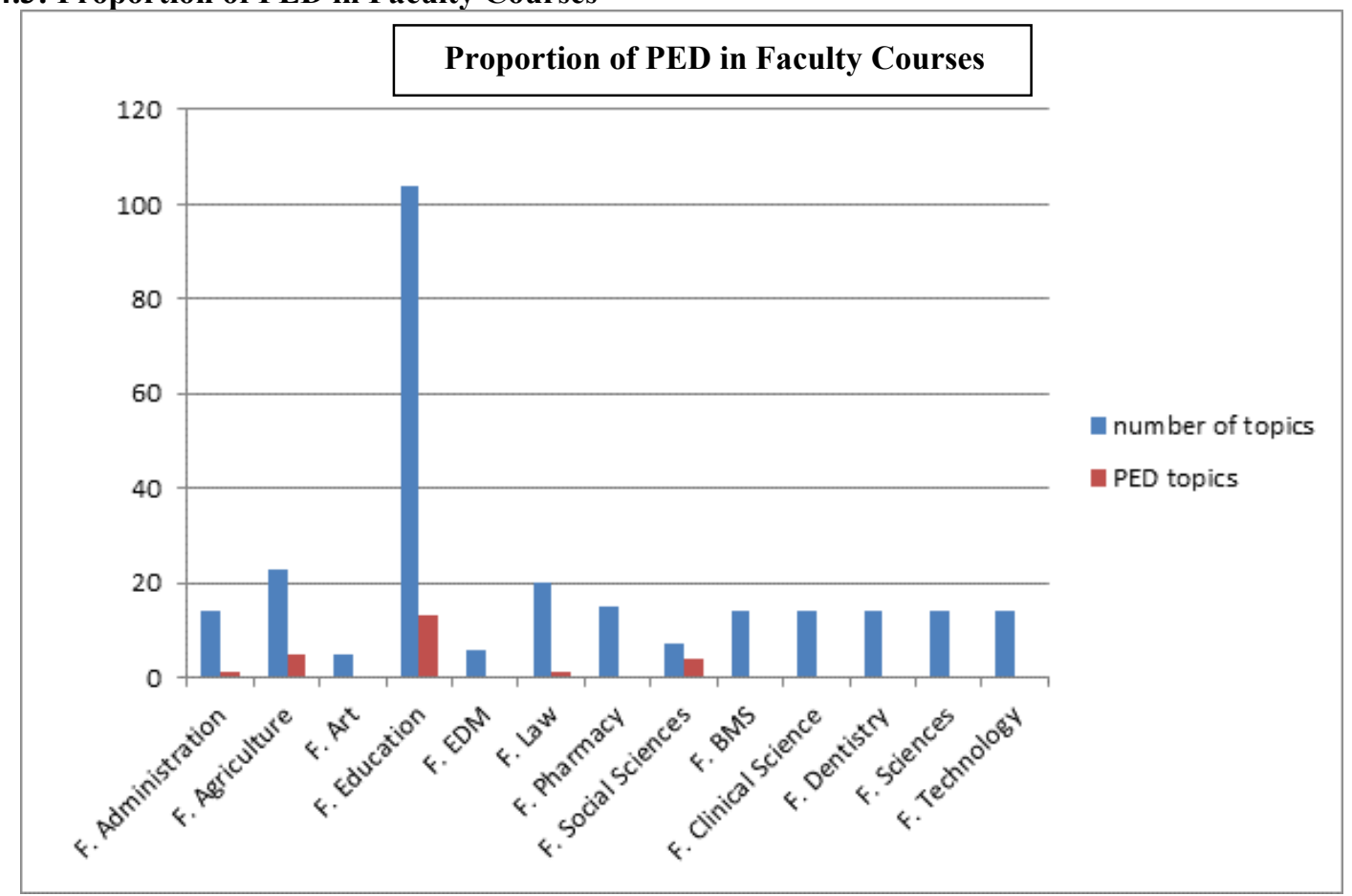

In light of the results shown above, it is evident that the attention paid on peace education elements by school faculties is too small, some faculties do not even reckon with it at all. While faculty of education has 13 out 104 topics, agriculture 5 out of 23, Social Sciences 4 out of 7, Law 1 out of 20, Administration 1 out of 14, and faculties like Art, EDM, Pharmacy, Basic Medical Science, Clinical Science, Sciences and Technology has none.

\subsection{THE QUANTITY OF PEACE EDUCATION AVAILABLE TO STUDENTS IN EACH FACULTY}

The author shall tackle this section by adding the quantity of Peace Education Diet in the Special Electives with the quantity of Peace Education Diet in each Faculty compulsory/combined courses in order to determine the quantity of peace education available to student in each faculty. 
TABLE4.62: The Quantity of PED in Special Electives added with the quantity of PED in each faculty compulsory/combined courses.

\begin{tabular}{|c|c|c|c|c|c|c|}
\hline \multirow[t]{2}{*}{$\mathbf{S} / \mathbf{N}$} & \multirow[t]{2}{*}{ FACULTY } & \multicolumn{2}{|c|}{$\begin{array}{l}\text { COMBINED } \\
\text { COURSES }\end{array}$} & \multicolumn{2}{|c|}{$\begin{array}{l}\text { SPECIAL } \\
\text { ELECTIVES }\end{array}$} & \multirow[t]{2}{*}{$\begin{array}{l}\text { PERCENTAGE } \\
\text { OF PED }\end{array}$} \\
\hline & & $\begin{array}{l}\text { NO OF } \\
\text { TOPICS }\end{array}$ & $\begin{array}{l}\text { NO } \\
\text { OF } \\
\text { PED } \\
\end{array}$ & $\begin{array}{l}\text { NO OF } \\
\text { TOPICS }\end{array}$ & $\begin{array}{l}\text { NO } \\
\text { OF } \\
\text { PED }\end{array}$ & \\
\hline 1. & Faculty of Administration & 14 & 1 & 16 & -- & $3.3 \%$ \\
\hline 2. & Faculty of Agriculture & 23 & 5 & 7 & -- & $16.6 \%$ \\
\hline 3. & Faculty of Art & 5 & -- & 14 & 5 & $26.3 \%$ \\
\hline 4. & Faculty of Education & 104 & 13 & 16 & 9 & $18.3 \%$ \\
\hline 5. & $\begin{array}{l}\text { Faculty of Environmental } \\
\text { Design } \\
\text { Management(EDM) }\end{array}$ & 6 & -- & 30 & -- & -- \\
\hline 6. & Faculty of Law & 20 & 1 & 28 & 4 & $10.4 \%$ \\
\hline 7. & Faculty of Pharmacy & 15 & -- & 25 & 4 & $10 \%$ \\
\hline 8. & Faculty of Social Sciences & 7 & 4 & 27 & 9 & $38.2 \%$ \\
\hline 9. & $\begin{array}{l}\text { Faculty of Basic Medical } \\
\text { Science(BMS) }\end{array}$ & 14 & -- & 14 & 4 & $14.2 \%$ \\
\hline 10. & Faculty of Clinical Science & 14 & -- & 9 & 3 & $13 \%$ \\
\hline 11. & Faculty of Dentistry & 14 & -- & -- & -- & -- \\
\hline 12. & Faculty of Sciences & 14 & -- & 3 & -- & -- \\
\hline 13. & Faculty of Technology & 14 & -- & 5 & -- & -- \\
\hline
\end{tabular}

FIG 5: Proportion of PED in OAU Special Elective and combined faculty Courses together.

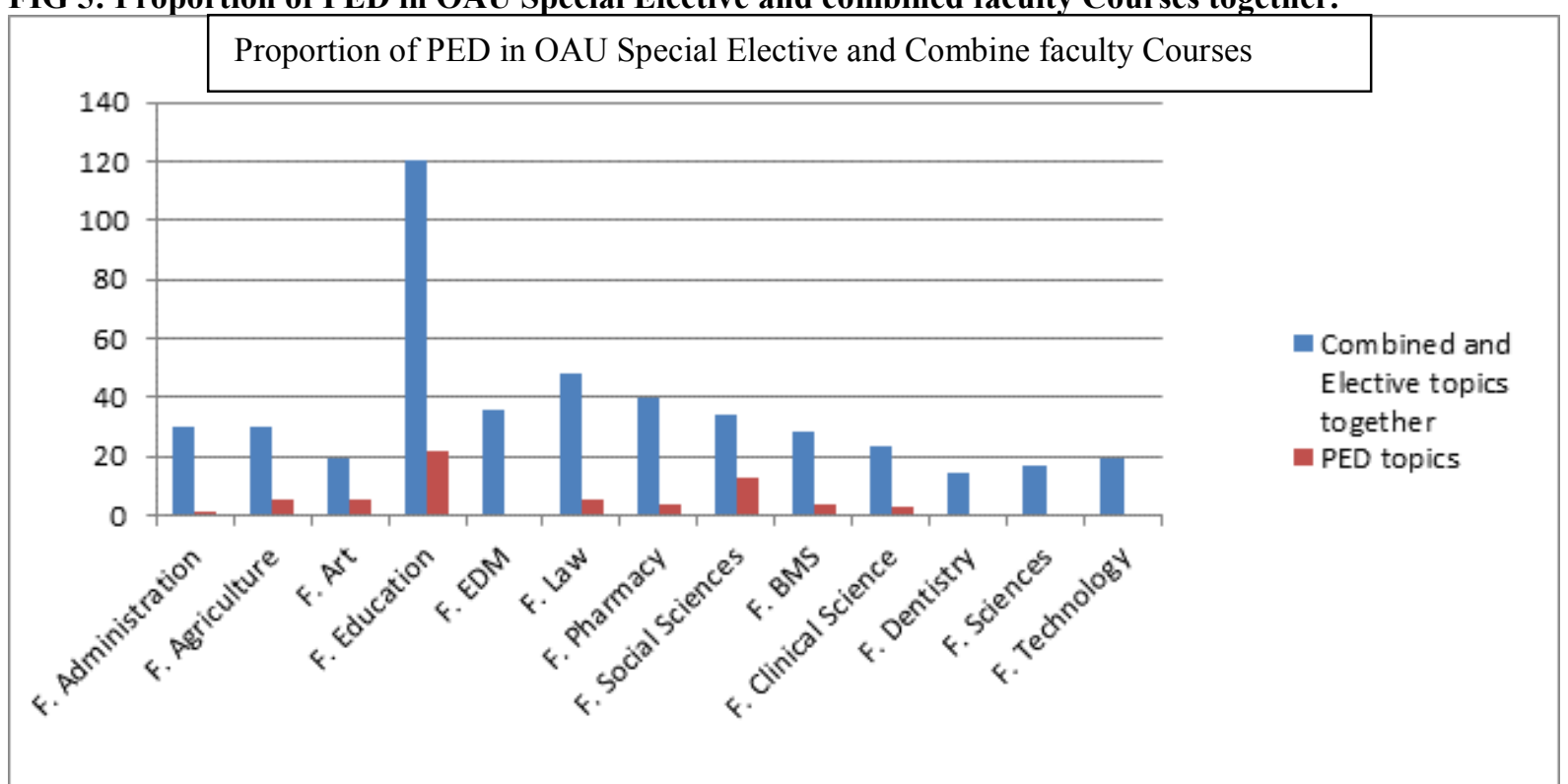

Dwelling on the results presented above, OAU faculties are relatively too low in terms of peace education contents, and some faculties do not even touch on peace education at all. According to the table above, the faculty of Social Sciences possess the highest percentage in peace content which is $38.2 \%$ followed by the faculty of Art having 26.3\%, Education has 18.3\%; Agriculture has 16.6\%, Basic medical Science 14.2\%, Clinical Science 13\%, Law 10.4\%, Pharmacy 10\%, Administration 3.3\% while Faculties of Environmental Design and Management, Science, Technology and Dentistry have none. Integrative Theory of Peace Education, "Peace education is the only route to true civilization and true civilization is both peaceful and peace creating." Therefore to produce a truly civilized citizen or peaceful citizens with university education, peace education plays a vital part. University education is meant to make university students civilized and transformed citizens, according to the above results, peace reservoir of the faculty having the highest peace education content (i.e. Social Sciences) is below average (i.e. $38.2 \%$ ), but any curriculum that is to produce a peaceful or truly civilized citizens should be able to possess peace education diet that is above $50 \%$. 


\section{SUMMARY, CONCLUSION AND RECOMMENDATIONS.}

The findings of this study reveal that the university curriculum of Obafemi Awolowo University in Nigeria contains some peace education topics that are based on some areas of peace education but meagre. However, effective implementation of peace education curriculum requires the integration of peace concept and strategies into all aspects of instruction to cut across boundaries and educational practices including Health Sciences, Technology and others. This is because peace education is not just about adding topics or themes to the curriculum. It is about mind transformation through the acquisition of appropriate skills, values and attitude which will empower the learner to seek and maintain peace. The implication is that peace education goes beyond subject matter issues to include all aspects of learning that touch on the behaviour of the learner. The essential thing is to teach every subject with peace education orientation. In this regard, Swee-Hin (2000:25) states that:

Teachers and educators in all levels of schooling undoubtedly constitute a vital link in the web of building a culture of peace and non-violence for the children and adults of the world. For example, non-violence and a holistic peace education framework needs to be integrated into curriculum areas in terms of content (knowledge and texts) and pedagogies (participatory and cooperative).Classroom management skills can endorse non-violence principles and practices of conflict resolution.

The findings that learners are neither involved in activities that demonstrate values and principles in peace education nor do they frequently engage in peace-making skill acquisition activities indicate a lacuna in the implementation of peace education in Nigeria. During the interview discussion, most of the respondents told the researcher that they do not have enough time to engage the students in peace oriented activities.

Peace education is not exactly like the other university courses. It is more concerned with the affective than the cognitive domain of educational objectives. Consequently experiential learning is the recommended mode of instruction (Staub, 2002 and Bar-Tal, 2002).The learners acquire knowledge by doing or by engaging in appropriate actions. In fact Bar-Tal $(2002,33)$ insists that "students need to live under the conditions described in peace education in order to internalize its objectives". The essential thing is to provide learners with peace infused skill and activity-based lessons "that together build the attitudes, values and behaviour of constructive living within the community" (UN, 2004.4) the implication is that lecturers should create appropriate scenarios for students to learn the need for peace as well as the strategies for peace. These peace strategies are "peacekeeping, peace-making and peace building" (Harris and Morrison, 2003:15). It is only through the practice of these strategies of peace that learners can internalize the objectives, values and principles in peace education. The findings of this study also imply that lecturers should be conversant not only with the concept of peace education but also with its instructional strategies. This will enable the lecturers use every opportunity in the instructional process to develop in the learners a culture of peace and non-violence.

Apart from the fact that this will lead to the establishment of a society where human beings work together to resolve conflicts, as well as respect human dignity, it will also lead to development. UNDP (2006:2) confirms that "there is an indispensable link between peace and development"

\section{CONCLUSION AND RECOMMENDATIONS}

Findings of this study have shown that peace education is yet to be effectively implemented in the Nigerian university curriculum. The major problem is that a good number of the lecturers do not understand the peace education concept or its objectives, principles and strategies. This buttresses the need for adequate lecturer preparation in this area of study. This is to ensure that these lecturers can effectively help learners develop the ability to tolerate others and to resolve conflict without violence. In this regard the following recommendations are made:

- Seminars and workshops should be organized for university lecturers to enable them acquire the pedagogical expertise for implementing peace education curriculum.

- The Nigerian University Curriculum Planners (NUC) should integrate peace contents in all the courses recommended for all universities.

- Principles and strategies of peace education should be integrated into basic methodology courses taught in teacher training institutions.

- Peace education topics should be added to all courses in the university curriculum.

- Film producers should endeavour to be projecting peace heroes more often than war heroes.

- Religious leaders should continue to use every opportunity to denounce violence and project peace.

- The Federal Government should institute peace merit award to be given to deserving individuals.

\section{REFERENCES}

Abdu'l-Bahá. (Paris talks). Paris talks (10th edn). London: ( Baha'i Publishing Trust).

Allport, G. W. ((1954) ). In The nature of prejudice. Reading, MA, Addison-Wesley.

Bajaj, M. (. ((2008). ). Encyclopedia of Peace Education. Charlotte, North Carolina:: Information Age Publishing, 
Inc.

Bar-Tal, D. In Shared beliefs in a society. (2000) : Thousand Oaks, CA, Sage.

Bar-Tal, D. ((1999) ). In The elusive nature of peace, in: A. Raviv, L. Oppenheimer \& D. Bar-Tal (Eds). San Francisco, CA, Jossey-Bass.

Boutros-Ghali, B. (1992.). An Agenda for Peace: Preventive Diplomacy, Peacemaking, and Peacekeeping. New York: United Nations.

Danesh, H. B. ((2004) ). In Conflict-free conflict resolution (CFCR) (pp. 11(2), 55-84.).

Danesh, H. B. (2002, September). In Education for Peace: breaking the cycle of violence. Paper (pp. p. 32-39.). New York, Office of Social and Economic Development, United Nations.

Deusch, M. a. (2000). The handbook of conflict resolution: Theory and practice. San Francisco: Jossey-Bass.

Deutsch, M. (1973.). The resolution of social conflict: Constructive and destructive processes. New Haven: Yale University Press.

Fisher, R. (1990.). The social psychology of intergroup and international conflict resolution. New York: SpringerVerlag.

Galtung, J. ((1969). ). Violence, Peace and Peace Research. Journal of Peace Research, 6, 167-191.

Gutek, G. L. ((2006). ). American Education in a Global Society. International and Comparative Perspectives. Long Grove, Illinois: Waveland Press, Inc.

Haavelsrud, M. ((2008). ). Conceptual Perspectives in Peace Education, Encyclopedia of Peace Education . Charlotte, North Carolina: Information Age Publishing, Inc.

Harris, I. M. ((2008)). History of Peace Education. In M. Bajaj (Ed.), Encyclopedia of Peace Education. Charlotte, North Carolina: Information Age Publishing, Inc.

Harris, I. M. ((2004). ). Peace Education Theory. Journal of Peace Education, 1, 5-20.

Harris, I. M. ((2003). ). Peace Education. 2nd ed. London: : McFarland and Co.

In Y. Iram (Ed.). ((2006).). Education toward a Culture of Peace (pp. 57-71). Greenwich, Connecticut: Information Age Publishing, Inc.

Johnson, D. W. ((1981). ). Effects of Cooperative, Competitive, and Individualistic Goal Structures on Achievement: A Meta-.

Kriesberg, L. (1998.). Constructive conflict: From escalation to resolution. Lanham, MD: Rowman \& Littlefield.

Montessori, M. ((1943). ). Education and Peace. Chicago: Henry Regnery.

Staub, E. (2002). In contents and process of peace education (pp. pp. 73-88.). (New York, Lawrence Erlbaum) .

Teilhard de Chardin, P. ((1961) ). In The phenomenon of man. (New York, Harper \& Row).

Vrience, L. ((1999) ). Children, war, and peace: a review of fifty years of research from the perspective. San Francisco, CA, Jossey-Bass.

Waterkamp, D. ((2006).). Peace Education and the Concept of Mankind. 